1 Short title: Chitosan induces defences in tomato root exudates

2

3 Corresponding author:

4 Marta Suarez-Fernandez

5 Department of Marine Sciences and Applied Biology, Laboratory of Plant Pathology,

6 University of Alicante, 03690 Alicante, Spain

7 Laboratory of Plant Pathology, Multidisciplinary Institute for Environmental Studies

8 (MIES) Ramon Margalef, University of Alicante

9 San Vicente del Raspeig, Alicante, 03690, Spain

10 Email: marta.suarez@ua.es

11 Phone: +34 965903400 ext. 3280

12 Fax: +34965909897

13

14

15

16

17

18

19

20

21

22

23

24

25

26

27

28

29

30

31

32

33 


\section{Chitosan induces plant hormones and defences in tomato root exudates}

40 Marta Suarez-Fernandez ${ }^{\mathrm{a}, \mathrm{b}^{*}}$, Frutos Carlos Marhuenda-Egea ${ }^{\mathrm{c}}$, Federico Lopez-Moya ${ }^{\mathrm{b}}$,

41 Marino B. Arnao ${ }^{d}$, Francisca Cabrera-Escribano ${ }^{e}$, Maria Jose Nueda ${ }^{\dagger}$, Benet Gunség

42 and Luis Vicente Lopez-Llorca ${ }^{a, b}$

43 aLaboratory of Plant Pathology, Multidisciplinary Institute for Environmental Studies

44 (MIES) Ramon Margalef, University of Alicante, 03080 Alicante, Spain

45 bepartment of Marine Sciences and Applied Biology, Laboratory of Plant Pathology,

46 University of Alicante, 03690 Alicante, Spain

47 'Department of Agrochemistry and Biochemistry, Multidisciplinary Institute for

48 Environmental Studies (MIES) Ramon Margalef, University of Alicante, 03690 Alicante,

49 Spain

50 dDepartment of Plant Biology (Plant Physiology), University of Murcia, Campus de 51 Espinardo, 30100 Murcia, Spain

52 eDepartment of Organic Chemistry, Chemistry Faculty, University of Seville, C/ 53 Profesor Garcia Gonzalez 1, 41012 Seville, Spain

54 'Statistics and Operational Research Department, University of Alicante, 03690, 55 Alicante, Spain

56 'Plant Physiology Laboratory, Faculty of Biosciences, Universidad Autonoma de Barcelona, 08193 Bellaterra, Spain

*Corresponding Author: Marta Suarez-Fernandez (marta.suarez@ua.es)

60

\section{One-sentence summary}

62 Chitosan depolarizes plasma membrane of root cells, causing the secretion of 63 hormones, lipid signalling and plant defence compounds, including phenolics. These 64 root exudates inhibit soil-borne pathogens.

\section{Author contributions}

L.V.L.L. conceived the original screening and research plans and wrote the paper; M.S.F. performed the main experiments and wrote the paper; F.C.M.E. analysed the fluorescence, ${ }^{1} \mathrm{H}$ NMR and HPLC-MS data; F.L.M. supervised the experiments and writing; M.B.A. provided technical assistance to phytomelatonin detection experiments; F.C.E. provided technical assistance to ${ }^{1} \mathrm{H}$ NMR experiments; M.J.N. performed the time series analyses; B.G. performed electrophysiological and vital staining experiments; M.S.F. agrees to serve as the author responsible for contact and ensures communication. 


\section{Funding Information}

76 This work was supported by AGL 2015 66833-R Grant from the Spanish Ministry of

77 Economy and Competitiveness and H2020 MUSA 727624 European Project.

\section{ABSTRACT}

In this work, we use electrophysiological and metabolomic tools to determine the role of chitosan as plant defence elicitor in soil for preventing or manage root pests and diseases sustainably. Root exudates include a wide variety of molecules that plants and root microbiota use to communicate in the rhizosphere. Tomato plants were treated with chitosan. Root exudates from plants were analysed at 3, 10, 20 and 30 days after planting (dap). We found, using High Performance Liquid Chromatography (HPLC) and Excitation Emission Matrix (EEM) fluorescence, that chitosan induces plant hormones, lipid signalling and defence compounds in tomato root exudates, including phenolics. High doses of chitosan induce membrane depolarization and affect membrane integrity. ${ }^{1} \mathrm{H}-\mathrm{NMR}$ showed the dynamic of exudation, detecting the largest number of signals in 20 dap root exudates. Root exudates from plants irrigated with chitosan inhibit ca. 2-fold growth kinetics of the tomato root parasitic fungus Fusarium oxysporum f. sp. radicis-lycopersici. and reduced ca. 1.5-fold egg hatching of the rootknot nematode Meloidogyne javanica.

Keywords: Chitosan, Root exudates, Membrane potential, Lipid signalling compounds,

96 Oxylipins, Pant defences, Plant hormones, Phytomelatonin, Metabolites, EEM-

97 Fluorescence analysis, HPLC, ${ }^{1} \mathrm{H}$ NMR, Soil-borne pathogens, Tomato 


\section{INTRODUCTION}

105

106 Chitosan is a linear polymer of $\beta$-(1-4)-linked N-acetyl-2-amino-2-deoxy-D-glucose 107 (acetylated) and 2-amino-2-deoxy-D-glucose (deacetylated) (Kaur and Dhillon, 2014). It 108 is generally obtained by partial deacetylation of chitin (Ravi Kumar, 2000), which is the 109 second most abundant polysaccharide in nature after cellulose (Elieh-Ali-Komi and 110 Hamblin, 2016). Chitin is a major component of the cuticle of insects, exoskeleton of 111 crustaceans and fungal cell walls. Chitosan has been described as elicitor of plant 112 defences (Yin et al., 2016) and it is used in food crops such as tomato and tobacco (Iriti 113 and Faoro, 2008; El-Tantawy, 2009). Chitosan also propitiates accumulation of auxin

114 (mainly indoleacetic acid; IAA) in the apex of plant roots (Lopez-Moya et al., 2017).

115 Electrophysiology can monitor the response of plant roots to stress (Rodrigo-Moreno et 116 al., 2013). Membrane potential reflects the action of all pumps in the cell membrane to 117 maintain ion gradients (Alberts et al., 2002). Root cell membranes detect changes in 118 their environment and respond starting metabolic cascade reactions (Fürstenberg119 Hägg et al., 2013; Matzke and Matzke, 2013). Those reactions could lead to new 120 compounds of agronomic and ecological interest.

121 Rhizodeposition is the process of releasing organic compounds from roots to the 122 external medium. Plants exude a wide variety of low molecular weight organic 123 compounds (e.g. amino acids and small peptides, organic acids, hormones, sugars, 124 phenolics and other secondary metabolites) (Vivanco et al., 2002). Resolving this 125 complex mixture requires the use of diverse metabolomics technologies (Escudero et 126 al., 2014; van Dam and Bouwmeester, 2016). Root exudates are paramount in plant127 microbe interactions in the rhizosphere, including beneficial and pathogenic microbes 128 and play a key role in signalling (Hirsch et al., 2003; Bais et al., 2006; Walker et al., 129 2009; Zhang et al., 2019; Valette et al., 2020). Metabolomics can help us to understand 130 the chemical interactions between organisms in the rhizosphere, as well as the 131 importance to uncover toxic compounds (Baldrian, 2019). Metabolomics allows 132 detection of phenolic compounds by fluorescence (Hupp et al., 2019). Phenolics have 133 diverse functions in plants, but one of the most important is their role in plant defence 134 and signalling (Mandal et al., 2010). Hormones are also signalling molecules that can 135 also be found using metabolomics (Street and Schenk, 1981; Li et al., 2009; Yang et 136 al., 2015). Auxin (e.g. IAA), salicylic acid (SA), jasmonic acid (JA) and abscisic acid 137 (ABA) are produced in response to physiologic or metabolic changes (Asami and 138 Nakagawa, 2018). Phytomelatonin is considered a master regulator in plant stress 139 conditions (Arnao and Hernández-Ruiz, 2019a; Arnao and Hernández-Ruiz, 2019b; 140 Arnao and Hernández-Ruiz, 2019c) and also involved in the regulation of several plant 
141 hormones (Arnao and Hernández-Ruiz, 2018). Phytomelatonin promotes growth and

142 root appearance (Hernández-Ruiz et al., 2005; Arnao and Hernández-Ruiz, 2007).

144 The aim of this work is to determine the effect of chitosan on plant rhizodeposition.

145 Root electrophysiology allows us to monitor the effect of chitosan on membrane 146 functionality. In addition, metabolomic techniques are used to determine the effect of 147 how chitosan modulates the composition of root exudates. Finally, we test these 148 exudates against root pathogens which threaten food security worldwide. This will 149 allow us to validate the role of chitosan as a plant defence inducer in soil for preventing 150 or managing root pests and diseases sustainably.

\section{RESULTS}

\section{Chitosan depolarizes plasma membrane and reduces tomato root cell viability}

155 Chitosan $\left(1\right.$ and $\left.2 \mathrm{mg} \cdot \mathrm{mL}^{-1}\right)$ depolarizes $(\mathrm{p}<0.001)$ plasma membrane of tomato root 156 cells (Figure 1A). This is reflected in loss of cell viability (PI red staining, Figure 1B).

157 Roots incubated with $2 \mathrm{mg} \cdot \mathrm{mL}^{-1}$ chitosan show a curved morphology and dark 158 precipitates. Conversely, a low dose of chitosan $\left(0.1 \mathrm{mg} \cdot \mathrm{mL}^{-1}\right)$ does not alter plasma 159 membrane potential. However, these roots show both viable (FDA green staining) and 160 non-viable cells, indicating some chitosan damage. Untreated tomato roots show 161 mostly viable cells, stained with FDA. The slight red staining is due to natural senescence of root epidermic cells (Figure 1B, arrow).

\section{Chitosan induces hormones and phenolic compounds in root exudates}

165 EEM Fluorescence analysis of root exudates resulted in 3 components (Figure 2, 166 Supplemental Table 1). Components 1 and 3 are the most induced $(p<0.01)$ by 167 chitosan. Component 1 includes a putative fluorophore with Ex/Em wavelength pair of $168315 / 430 \mathrm{~nm}$, which could correspond to SA (Street and Schenk, 1981). Component 3 169 includes Ex/Em wavelength pairs of 245/384 and 265/384 nm, which may correspond 170 to aromatic amino acids and peptides (Yang et al., 2015; Table 1).

171 Chitosan induces other hormones in tomato root exudates (Figure 3). High doses of 172 chitosan ( 1 and $\left.2 \mathrm{mg} \cdot \mathrm{mL}^{-1}\right)$ induce $(\mathrm{p}<0.01)$ IAA accumulation in root exudates (Figure $1733 A)$. Plant defence hormones (SA, JA and ABA) are also significantly induced $(p<0.05)$ 174 by chitosan $\left(1 \mathrm{mg} \cdot \mathrm{mL}^{-1}\right)$ in tomato root exudates (Figures 3B-3D). This effect is lost at 2 $175 \mathrm{mg} \cdot \mathrm{mL}^{-1}$ chitosan. This could be the result of a root systemic damage caused by large 176 chitosan concentrations. In view of the effect of chitosan on plant hormone 177 homeostasis, endogenous phytomelatonin in roots was evaluated. Chitosan $\left(1 \mathrm{mg} \cdot \mathrm{mL}^{-}\right.$ 
$\left.17{ }^{1}{ }^{1}\right)$ causes a slight rise on phytomelatonin content in tomato root cells (Figure 3E).

179 Phytomelatonin levels detected in tomato root exudates are close to nil (Supplemental

180 Figure 1).

181

182 Chitosan induces de novo exudation of SA and phenolics in roots

183 In view of the results obtained with tomato roots elicited for 3 days with chitosan, we 184 irrigated tomato plants with a low dose of chitosan $\left(0.1 \mathrm{mg} \cdot \mathrm{mL}^{-1}\right)$ during 10,20 and 30 185 days and analysed de novo exudation in roots. Ten days after planting (dap), chitosan 186 increases de novo $(\mathrm{p}<0.01)$ exudation of a fluorescence signature putatively belonging 187 to SA (Figure 4, Table 1). Twenty dap, chitosan significantly increases $(p<0.001)$ 188 fluorescence intensity of Component 3, putatively assigned to phenolics (Mostofa et al., 189 2013; Parri et al., 2020) and SA derivatives (Street and Schenk, 1981). This tendency 190 is also found for Components 1 (putatively aromatic amino acids and peptides) and 2 191 (putatively IAA; Li et al., 2009), although differences are not significant. In late root 192 exudates (30 dap), fluorescence intensity decreases respect to early root exudates.

193 This could be due to root ageing and lignification. At this time, EEM Fluorescence 194 spectrum is separated into 2 Components only (Supplemental Table 1, Supplemental 195 Figure 2) with no differences respect to controls.

197 Metabolomic diversity of tomato root exudates varies with time

198 Pools were made to concentrate root exudates and avoid sample variability (Yuan et 199 al., 2015; Yang et al., 2016). Root exudates from 20 dap tomato plants (chitosan 200 treated and controls) displayed most NMR peaks (Figure 5). This may be because 201 older plants (30 dap) are more lignified (Cervilla et al., 2009) and display less 202 rhizodeposition. Manual curation of ${ }^{1} \mathrm{H}$ NMR profiles of root exudates from plants 10 , 20320 and 30 dap from chitosan treated plants and controls show no qualitative 204 differences and contain 31, 123 and 18 peaks respectively. Ninety-three peaks are 205 specific to 20 dap root exudates. Nine 20 dap specific peaks were identified as (Table 206 2): leucine/isoleucine (13), acetate (53), raffinose (99, 103), glucose (100), uracil (105 207 and 120), cinnamic acid (109, 119, 121), fumaric acid (109), p-aminobenzoic acid (112 208 and 122) and trigonelline $(125,130,131)$. Chitosan decreases $(p<0.05)$ acetate (peak 209 53) content in 20 dap root exudates. Six peaks, among them methanol (80) and formic 210 acid (129), are found 20 and 30 dap. Lactate (peak 36) and malate (peaks 62 and 64) 211 have been detected in all time points evaluated. All detected peaks are listed in 212 Supplemental Table 2. A representative ${ }^{1} \mathrm{H}$ NMR profile of tomato root exudates is 213 shown in Supplemental Figure 3. 
214 Chitosan induces lipid signalling and defence compounds in tomato root

\section{5 exudates}

216 Lipid signalling and defence compounds are putatively identified in 20 dap root

217 exudates (Figure 6). Oxylipins and other lipid signalling compounds, such as 13-epi-12

218 oxophytodienoic acid (OPDA, 293.7, +), myo-inositol-2,4-diphosphate (IDP, 341.7, +)

219 are up-regulated with chitosan. Two unidentified fatty acids (FA1, 313.8, +; FA2, 344.3,

$220+$ ) are slightly changed. Defence compounds such as glycerol-3-phosphate (G3P, m/z 221 191.0, mode -) and indol-3-carboxylic acid (I3CA, 290.8, +), involved in plant immunity 222 are up-regulated with chitosan. On the contrary, 3-(2 methyl propyl) pyridine (MPP, $223282.7,+$ ), is down-regulated. Glucaric acid (GA, 327.7, -), which interacts with the 224 pentose pathway, is also down-regulated.

\section{Root exudates from plants treated with chitosan inhibit soil-borne pathogens}

227 Soil-borne pathogens (fungi and nematodes) are inhibited by root exudates from plants treated with chitosan. Root exudates from chitosan-treated plants cause ca. 1.5-fold reduction $(p<0.05)$ on hatching of the root-knot nematode Meloydogine javanica eggs after 72 hours respect to tomato control root exudates (Figure 7A). These exudates also inhibit growth of Fusarium oxysporum f.sp. radicis-lycopersici (FORL) ca. 2-fold

232 respect to controls (Figure 7B). The chitosan resistant fungus Pochonia

233 chlamydosporia strain $123(\mathrm{Pc})$ does not show significant differences in growth with

234 both exudates over time (Figure 7C).

\section{DISCUSSION}

236 In this study we give evidences that chitosan induces plant defences in tomato root 237 exudates. High doses of chitosan are known to affect root growth (Lopez-Moya et al., 238 2017; Asgari-Targhi et al., 2018). Plasma membranes are likely to be a main target of 239 this molecule (Palma-Guerrero et al., 2010; Meisrimler et al., 2011; Jaime et al., 2012).

240 In this work, we show that increasing chitosan concentrations depolarize tomato root 241 cells plasma membrane and reduce viability. He et al., (2009) propose chitosan as a 242 potential cell penetration enhancer. This fact has been demonstrated using vital 243 staining in fungi (Palma-Guerrero et al., 2010) and, in this work, in root apices. These 244 effects of chitosan on roots are likely to modify rhizodeposition (Pitta-Alvarez and 245 Giulietti, 1999). Chitosan depolarisation on the membrane could trigger an increase of 246 reactive oxygen species (ROS) in the plant cell, resulting in a signal cascade that 247 modifies metabolic response (Pandey, 2017). ROS are known to alter chemical 248 components of the cell and lipids in particular. Consequently, lipid signalling 
249 compounds, including oxylipins (OPDA and IDP) are up-regulated in root exudates

250 from plants treated with chitosan (Dar et al., 2015). OPDA, a precursor of JA (Dave and

251 Graham, 2012), could explain the up-regulation of JA in these exudates. OPDA is

252 involved in plant defense by up-regulating detoxifying enzymes and secondary

253 metabolism pathways (Conconi et al., 1996; Savchenko et al., 2014). Oxylipins other

254 than jasmonates are probably also essential for the resistance of plants to pathogens

255 (Blée, 2002). IDP, which belongs to a family of compounds that act as messengers that

256 regulate cellular functions, including cell cycling, apoptosis, differentiation, and motility

257 (Majerus, 1992) is also up-regulated by chitosan. IDP is well-known intermediate of

258 metabolic and signalling pathways (Berridge, 1993; Williams et al., 2015; Freed et al.,

259 2020). Besides IDP, other lipids (eg. ramifed fatty acids) found in root exudates, could

260 be part of the plant immune response signalling induced by chitosan (Czékus et al.,

261 2020; Narula et al., 2020). Other plant defence compounds such as G3P and I3CA are

262 also up-regulated with chitosan. G3P is systemic acquired resistance (SAR) inducer in

263 plants (Chanda et al., 2011; Wang et al., 2019). I3CA, an indolic compound, also

264 induces plant resistance (Böttcher et al., 2014; Syeda and Riazunnisa, 2020) through

265 callose accumulation (Pastor-Fernández et al., 2019). On the other hand, GA, which

266 interacts with the pentose pathway (Moon et al., 2009), is down-regulated by chitosan.

267 We could assume that chitosan is causing plant stress and that interferes with its

268 primary metabolism and reduces pentose phosphate pathway.

269 Importance of chitosan in plant hormone production and systemic acquired response

270 has been widely demonstrated (Mika et al., 2010; Iglesias et al., 2019; Colman et al.,

271 2019; Fooladi-Vanda et al., 2019; Ma et al., 2019). We have found that increasing

272 chitosan leads to the accumulation of fluorescence compounds corresponding to

273 phenolics, as well as hormones related to plant growth and defence (JA, SA, ABA and

274 IAA). This correlation between chitosan and phenolics has been previously studied

275 (Pitta-Alvarez and Giulietti, 1999; Park et al., 2019; Jaisi and Panichayupakaranant,

276 2020; Samari et al., 2020). Chitosan enhances metabolic pathways (e.g.

277 phenylpropanoid) involved in the biosynthesis of phenolic compounds (Asgari-Targhi et

278 al., 2018; Fooladi-Vanda et al., 2019; Singh et al., 2020). A low dose of chitosan

279 enhances the plant immune response by plant hormone (JA and SA, mainly)

280 accumulation in root tissues (Lopez-Moya et al., 2017; Iglesias et al., 2019; Singh et

281 al., 2020). However, this effect has not yet been detected in tomato root exudates. In

282 addition, there is evidence that chitosan could be used as a substitute for commonly

283 used growth factors such as methyl jasmonate, auxins or cytokinins (Cui et al., 2012;

284 Sivanandhan et al., 2012; Ahmad et al., 2019; Acemi, 2020) due to its elicitor effects

285 (Salachna and Zawadzińska, 2014; Malerba and Cerana, 2016). Phytomelatonin has 
286 been recently considered a plant master regulator involved in abiotic and biotic

287 responses. In our work, exposure of tomato roots to increasing chitosan doses

288 accumulates phytomelatonin and hormones in roots and root exudates in a typical

289 biotic stress response (Arnao and Hernández-Ruiz, 2019c; Moustafa-Farag et al.,

290 2019). The decrease in levels of some plant hormones at toxic chitosan doses has also

291 been found for phenolics (Park et al., 2019). EEM Fluorescence signatures

292 corresponding to IAA ( $\mathrm{Li}$ et al., 2009) and SA (Miles and Schenk, 1970) are increased

293 by chitosan in tomato root exudates. These hormones are known to be up-regulated by

294 chitosan (Lopez-Moya et al., 2017; Fooladi-Vanda et al., 2019). SA and JA are related

295 to plant responses to stress (War et al., 2011). Therefore, chitosan can be an elicitor of

296 plant defences in root exudates (Benhamou, 1996). Our bioassays show that chitosan

297 induces root exudates inhibitory to root pathogenic fungus FORL and root-knot

298 nematode eggs without significantly affecting the growth and development of a

299 biocontrol fungus (Pc). The toxic effect of chitosan-derived exudates may be related to

300 the overproduction of SA which, in combination with chitosan induce SAR and reduce

301 infection by root-knot nematodes (Vasyukova et al., 2003; Singh et al., 2019).

302 Chitosan, moreover, by itself, is toxic to fungi such as Fusarium spp. (Palma-Guerrero

303 et al., 2010; Al-Hetar et al., 2011), and other studies show that plants treated with

304 chitosan reduce FORL infection (Benhamou and Thériault, 1992).

305

306 Chitosan depolarizes plasma membrane of tomato root cells, causing the secretion of

307 hormones, lipid signalling and plant defence compounds, including phenolics. This

308 process affects cell viability and rhizodeposition, so plant age must be considered

309 before applying chitosan, as well as the duration of applications. Our results have

310 proven that root exudates of chitosan-treated plants are able to reduce soil-borne

311 pathogens growth and development, which makes chitosan a promising tool for

312 preventing and managing pests and diseases in a sustainable way.

313

314 MATERIALS AND METHODS

315

316 Chitosan, plants, fungi and nematodes

317 Chitosan with $70 \mathrm{kDa}$ molecular weight and $80.5 \%$ deacetylation degree was used in

318 all experiments. Chitosan was obtained from Marine BioProducts $\mathrm{GmbH}$

319 (Bremerhaven, Germany) and made as in Palma-Guerrero et al. (2007). Tomato plants

320 (Solanum lycopersicum cv. Marglobe) were used in all experiments. Pochonia

321 chlamydosporia, isolate number 123 (ATCC no. MYA-4875; CECT no. 20929) was

322 isolated from Heterodera avenae eggs in south west Spain (Olivares-Bernabeu and 
323 Lopez-Llorca, 2002). Fusarium oxysporum f. sp. radicis-lycopersici (CBS 123668) was

324 obtained from CBS-KNAW culture collection. Meloidogyne javanica was obtained from

325 a field population and maintained in susceptible tomato plants. Nematode egg masses

326 were dissected from root-knot nematode infested roots and stored at $4^{\circ} \mathrm{C}$. Egg masses

327 were hand-picked and surface-sterilized as in McClure et al. (1973) with modifications.

\section{Root electrophysiology experiments}

330 Tomato seeds were surface sterilized using 1\% sodium hypochlorite and washed three

331 times 1 min each with sterile distilled water (SDW). Tomato seeds were then placed on

332 germination medium (GM, Glucose $10 \mathrm{~g} \cdot \mathrm{L}^{-1}$, Yeast Extract $0.1 \mathrm{~g} \cdot \mathrm{L}^{\cdot 1}$, Bactopeptone 0.1

$333 \mathrm{~g} \cdot \mathrm{L}^{-1}$, Technical Agar $\left.12 \mathrm{~g} \cdot \mathrm{L}^{-1}\right)$. GM plates with tomato seeds were placed at $4^{\circ} \mathrm{C}$ for 2

334 days for stratification and incubated at $24^{\circ} \mathrm{C}, 65 \%$ relative humidity $(\mathrm{RH})$, in the dark for

3355 days and in a photoperiod (16:8) for further 5 days. Plantlets were then placed

336 individually in a holder chamber filled with Gamborgs's B5 1:10 (Sigma; Gamborg et

337 al., 1968). Glass microcapillaries filled with $0.5 \mathrm{M} \mathrm{KCl}$ (tip diameter $<1 \mu \mathrm{m}$ ) were

338 inserted into root cortical cells until a stable basal potential was obtained (Gunsé et al.,

339 2016). Roots were exposed to increasing concentrations of chitosan $(0.1,1$ and 2

$340 \mathrm{mg} \cdot \mathrm{mL}^{-1}$ in Gamborgs's B5 1:10 medium) and membrane potentials were recorded. No

341 chitosan was used for control treatments. Between each change of chitosan

342 concentration, root medium was replaced for Gamborgs's B5 1:10 to check the

343 physiological status of the cell. At least 3 replicates were performed per treatment.

\section{Root vital staining}

346 Tomato plantlets were placed in Gamborgs's B5 1:10 liquid medium for one day for 347 acclimatization. Chitosan then was added at $0.1,1$ and $2 \mathrm{mg} \cdot \mathrm{mL}^{-1}$. Plants exposed only 348 to Gamborg's B5 1:10 were used as controls. Plantlets with treatments were incubated 349 for $24 \mathrm{~h}$. Roots were then stained with fluorescein diacetate (FDA), $5 \mathrm{mg} \cdot \mathrm{mL}^{-1}$ in 350 acetone diluted 1:250 in Dulbecco's phosphate-buffered saline (DPBS, ThermoFisher) 351 and propidium iodide (PI, $20 \mathrm{mg} \cdot \mathrm{mL}^{-1}$ in DPBS; Jones and Senft, 1985). Roots were 352 visualized using a Nikon Optiphot microscope using 10X objective with an attached 353 Nikon DS-5 M camera system using epifluorescence (Ex: 450-490 nm, Em: 520 nm). 354 Non-damaged cells show green FDA fluorescence and nuclei of damaged cells show 355 red PI fluorescence.

\section{Plant growth conditions}

358 Tomato plantlets (Experiment 1) were placed in $200 \mathrm{~mL}$ expanded polystyrene sterile 359 cups each containing $100 \mathrm{~cm}^{3}$ of sterilized sand. They were then incubated in a culture 
360 chamber (SANYO MLR-351H) at $65 \% \mathrm{RH}, 24^{\circ} \mathrm{C}$ with a 16:8 $\mathrm{h}$ (light:dark) photoperiod.

361 Plants were irrigated for 20 days with Gamborg's B5 basal mixture 1:10 keeping

362 moisture to field capacity. Plants were then removed, washed and introduced

363 individually in Magenta Boxes ( $575 \mathrm{~mL}$, Sigma). Each Box was filled with $50 \mathrm{~mL}$ of

364 Gamborg's B5 1:10 (control) or Gamborg's B5 1:10 amended with chitosan (0.1, 1, 2

$\left.365 \mathrm{mg} \cdot \mathrm{mL}^{-1}\right)$. Nine tomato plants were set per treatment. Plants were incubated for 3 days

366 as described above.

367 In Experiment 2, tomato plantlets were grown as for Experiment 1. Plants in cups were

368 then irrigated with 1:10 Gamborg's B5 basal mixture on its own or amended with 0.1

$369 \mathrm{mg} \cdot \mathrm{mL}^{-1}$ chitosan. Plants were incubated as before. Ten plants per treatment were

370 sampled 10, 20 and 30 days after planting (dap) for further analyses.

\section{Collection of root exudates}

373 In Experiment 1, root exudates accumulated for 3 days in Magenta Boxes were 374 collected and filtered through Miracloth (Calbiochem). Pools were made with the 375 exudates of 3 plants each. Root exudate pools were frozen at $-20^{\circ} \mathrm{C}$ until further use.

376 In Experiment 2, whole plants were removed, and their root systems washed in SDW.

377 De novo root exudates from these plants were collected by placing individual whole

378 plants in sterile plastic containers with $20 \mathrm{~mL}$ SDW per gram of root. Plants were

379 incubated in the dark at $24^{\circ} \mathrm{C}, 65 \% \mathrm{RH}$ for $24 \mathrm{~h}$. Plants were then removed, and root

380 exudates were collected by $0.22 \mu \mathrm{m}$ (Q-MAX) filtration and stored frozen at $-20^{\circ} \mathrm{C}$ until

381 used.

383 Emission Excitation Matrix (EEM) Fluorescence analysis

384 Two $\mathrm{mL}$ of each root exudate (Experiments 1 and 2) were collected and EEM

385 Fluorescence spectra were obtained with a spectrofluorometer (Jasco FP-6500)

386 equipped with a 150W Xenon lamp. Contour maps of EEM fluorescence spectra were

387 obtained from water extracts of whole root exudates (10 samples) or pools. The

388 emission (Em) wavelength range was fixed from 220 to $460 \mathrm{~nm}$ in $5 \mathrm{~nm}$ steps, whereas

389 the excitation (Ex) wavelength was fixed from 220 to $350 \mathrm{~nm}$ in $2 \mathrm{~nm}$ steps. The slit

390 width was $5 \mathrm{~nm}$ and the root exudates were placed in a $1 \mathrm{~cm}$ path length fused quartz

391 cell (Hellma). The UV-visible spectra of samples were acquired (SHIMADZU UV-160

392 spectrophotometer, $200-800 \mathrm{~nm}, 1 \mathrm{~cm}$ quartz cuvette). Absorbance was always lower

393 than $0.1\left(O D_{\text {units }}\right)$ at $254 \mathrm{~nm}$ in order to reduce the absorbance of the solution to

394 eliminate potential inner filter effects (Mobed et al., 1996). EEM fluorescence spectra of

395 root exudates were analysed using Parallel Factor Analysis (PARAFAC) as in Ohno 
396 and Bro (2006). PARAFAC model Components were calculated for each treatment and

397 time.

398

399 Plant hormone analysis

400 Root exudate pools (Experiment 1) were lyophilized to analyse Indoleacetic Acid (IAA),

401 Abscisic Acid (ABA), Salicylic Acid (SA) and Jasmonic Acid (JA) by Ultra Performance

402 Liquid Chromatography-Mass Spectrometry (UPLC-MS). Material was extracted with

403 80\% Methanol-1\% Acetic acid. Deuterium-labelled hormones (purchased from Prof. L

404 Mander-Canberra, OIChemim Ltd. -Olomouc): $\left[{ }^{2} \mathrm{H}_{5}\right] \mathrm{IAA},\left[{ }^{2} \mathrm{H}_{4}\right] \mathrm{SA}$ and $\left[{ }^{2} \mathrm{H}_{6}\right]$ ABA were

405 added as internal standards. For quantification of JA, dhJA was used instead.

406 For collecting the fractions containing SA, ABA and JA; extracts were passed

407 consecutively through HLB (reverse phase), MCX (cationic exchange) and WAX (ionic

408 exchange) columns (Oasis $30 \mathrm{mg}$, Waters), as described in Seo et al. (2011). The final

409 residue was dissolved in 5\% Acetonitrile - 1\% Acetic acid and separated by reverse

410 phase UPHL chromatography (2.6 $\mu \mathrm{m}$ Accucore RP-MS column, 100 mm length $\times 2.1$

411 mm i.d.; ThermoFisher Scientific) with a $5 \%$ to $50 \%$ acetonitrile gradient. Hormones

412 were analysed by electrospray ionization and targeted-SIM using a Q-Exactive

413 spectrometer (Orbitrap detector, ThermoFisher Scientific). Concentrations of hormones

414 in extracts were determined using embedded calibration curves and the Xcalibur 4.1

415 SP1 build 48 and TraceFinder programs. We thank Dr Esther Carrera by hormone

416 quantification carried out at the Plant Hormone Quantification Service, Valencia, Spain

417 (www. ibmcp.upv.es).

418 Phytomelatonin was also tested in both exudates and tissues. Ten-day old seedlings 419 were grown with chitosan $\left(0.1,1,2 \mathrm{mg} \cdot \mathrm{mL}^{-1}\right)$ in Gamborg's B5 1:10 for 3 days. Plants 420 exposed to Gamborg's B5 1:10 only were used as control. For each treatment, 0.2-0.3 $421 \mathrm{~g}$ of roots were dried onto sterile paper and placed in a $4 \mathrm{~mL}$ polypropylene tube with 3 $422 \mathrm{~mL}$ ethyl acetate. Samples were shaken at $120 \mathrm{rpm}$ and $4^{\circ} \mathrm{C}$ in the dark overnight. 423 Roots were removed and solvent evaporated under vacuum. The dry residue was 424 resuspended in $1 \mathrm{~mL}$ acetonitrile and filtered by $0.22 \mu \mathrm{m}$. Phytomelatonin from root 425 tissues was quantified by HPLC with fluoresecence detection with Ex/Em wavelength 426 pair of $280 / 348 \mathrm{~nm}$, as in Hernández-Ruiz et al. (2005). For root exudates, three 427 samples of $1 \mathrm{~mL}$ of Experiment 1 pools were used. Phytomelatonin was extracted and 428 analysed as described above.

\section{Nuclear Magnetic Resonance ('H NMR)}


431 Root exudates from Experiment 2 were pooled 5 by 5 , lyophilized and resuspended in

$4321 \mathrm{~mL}$ of $\mathrm{D}_{2} \mathrm{O}$ (deuterated water). Two pools were obtained from each treatment and 433 time.

434 Six hundred microliters of filtered pools were placed in a $5 \mathrm{~mm}$ NMR tube with $0.75 \%$

435 3-(trimethylsilyl)propionic-2,2,3,3- $\mathrm{d}_{4}$ acid sodium salt (TSP) and $0.002 \mathrm{~g}$ sodium azide.

$436{ }^{1} \mathrm{H}$ NMR experiments were performed on a Bruker AVIII $700 \mathrm{MHz}$ (CITIUS, University

437 of Sevilla, Spain). The number of scans was 256 and the experiments were carried out

438 at $298 \mathrm{~K} .{ }^{1} \mathrm{H}$ chemical shifts were internally referenced to the TSP at $\delta 0.00 .{ }^{1} \mathrm{H}$ NMR 439 spectra were aligned using TopSpin ${ }^{\mathrm{TM}}$ (Bruker).

440 Sensitivity of NMR is different in each region. For region I (organic-acid and amino-acid 441 region), the threshold was set in 0.1 . For II (sugars/polyalcohols region) and III 442 (phenolics/aromatic compounds region) peaks showed less intensity, consequently the 443 threshold was set in 0.01 and 0.001 respectively.

High Performance Liquid Chromatography Electrospray lonization tandem Mass Spectrometry (HPLC-ESI-MS)

448 Chromatography system with an Agilent 1100 Series model coupled to a UV-visible 449 variable wavelength detector and a mass spectrometer with ion trap analyser Series

450 LC/MSD Trap SL (Agilent, Santa Clara, CA). The mass spectrometer was operated in 451 the positive and negative ESI modes, and the ion spray voltage was set at $4 \mathrm{kV}$. Mass 452 range was set from 50 to 350 atomic mass units. Nitrogen was used as carrier gas (70 453 psi), and the ion transfer capillary heated to $350^{\circ} \mathrm{C}$. Injections were carried out using an 454 HTC Pal autosampler (CTC Analytics, Zwingen, Switzerland) equipped with a $20 \mu \mathrm{L}$ 455 sample loop.

456 Pools of 20 dap tomato root exudates (Experiment 2) were infused into the flow of the 457 HPLC system $(10 \mu \mathrm{L})$ through a T connection under the following conditions: flow rate, $4581 \mathrm{~mL} \cdot \mathrm{min}^{-1}$. Ultrapure water with $0.1 \%$ Formic Acid was used as Solvent $A$, whereas $459 \mathrm{MeOH}$ with $0.1 \%$ Formic Acid was used as Solvent B. From 0-15 min Solvent B was 460 kept at $10 \%$ and afterwards a gradient to $90 \%$ was established during 20 min and 461 decreased again to $10 \%$ until minute 25 . The LC separations were carried out with a 462 Poroshell 120 EC-C18 column, (4.6 x 100mm, 2.7 $\mu \mathrm{m}$-Agilent Technologies-). Runs 463 were performed at $25 \stackrel{\circ}{\circ}$. Raw data were transformed as explained in Marhuenda464 Egea et al. (2013).

465 Partial Least Squares Regression Discriminant Analyses (PLSLDA) show that m/z 466 intensities depend on treatment. Loading values lower than 0 indicate that $\mathrm{m} / \mathrm{z}$ intensity 467 is higher in chitosan-treated plant root exudates. A threshold was set at \pm 0.2 to identify 
$\mathrm{m} / \mathrm{z}$ with significant variations. Datasets were placed in Dryad repository

469 (https://doi.org/10.5061/dryad.ghx3ffbkb).

470

471

472

473

474

475

476

477

478

479

480

481

482

483

484

485

486

487

488

489

490

491

492

493

494

495

496

497

498

499

500

501

502

503

\section{Evaluation of tomato root exudates on fungi and nematode eggs}

Bioassays were performed in 96-well plates (Thermo Scientific) using 20 dap root exudate pools obtained in Experiment 2. For fungal experiments, $200 \mu \mathrm{L}$ of exudate and conidia were added per well to reach a concentration of $10^{6}$ conidia $\cdot \mathrm{mL}^{-1}$. Each exudate was analysed by triplicate and for each treatment, there were two pools of exudates. For both, FORL and $\mathrm{Pc}, \mathrm{OD}_{490}$ was calculated after 4 and 8-days respectively using a microplate reader (Tecan SPECTRAfluor). Results were handled with XFluor Software ${ }^{T M}$. For time series with FORL and Pc, the relation between two variables is not linear. In both cases, Smoother Model Lowess ("Locally weighted regression") was applied (Cleveland, 1979).

To evaluate the effects of root exudates on root-knot nematode eggs, experiments were performed with $200 \mu \mathrm{l}$ of exudate or water (control) containing $100 \mathrm{M}$. javanica eggs each. Hatching percentage was scored using an inverted microscope after $72 \mathrm{~h}$ incubation at $30^{\circ} \mathrm{C}$.

\section{Statistical analyses}

EEM Fluorescence data was analysed by PARAFAC, as described above, and the contribution of the Components 1,2 and 3 analysed by ANOVA tests. The level of significance in all cases was 95\%. All statistical analyses were performed using GraphPad Prism version 7.00 (GraphPad Software, La Jolla California, USA, https://www.graphpad.com/).

HPLC-ESI-MS data were processed using a Partial Least Square (PLS) regression model (Verboven and Hubert, 2005; Marhuenda-Egea et al., 2013) Classical PCA were also performed to display and group data (Verboven and Hubert, 2005). This data analysis was carried out using the LIBRA toolbox (available at http://wis.kuleuven.be/stat/robust/software).

\section{Acknowledgements}

This work was supported by AGL 2015 66833-R Grant from the Spanish Ministry of Economy and Competitiveness and H2020 MUSA 727624 European Project. Thanks are due to members of the Plant Pathology Laboratory of the University of Alicante, for 
bioRxiv preprint doi: https://doi org/101101/2020.06.09.142653, this version posted June 11, 2020. The copyright holder for this preprint (which was not certified by peer review) is the author/funder, who has granted bioRxiv a license to display the preprint in perpetuity. It is made available under aCC-BY-NC-ND 4.0 International license.

504 their help and support. Authors also wish to thank Mr Arnau Hernández Royo for his

505 help conducting electrophysiological and microscopy experiments.

506

507 Conflicts of Interest

508 The authors declare no conflict of interest.

509 


\section{Tables}

\section{1}

512 Table 1. Excitation and emission pairs of coordinates for each PARAFAC model per time.

513 Abbreviations $\mathrm{SA}=$ Salicylic Acid, IAA = Indole Acetic Acid, dap = days after planting, $\mathrm{C} 1=$

514 Component $1, \mathrm{C} 2$ = Component $2, \mathrm{C} 3$ = Component 3.

\section{Time Excitation $(\mathrm{nm}) \quad$ Emission $(\mathrm{nm}) \quad$ Compound}

\begin{tabular}{|c|c|c|c|}
\hline 3 dap & $\begin{array}{c}\text { C1: } 240 / 315 \\
\text { C2: } 230 / 280 \\
\text { C3: } 245 / 265 / 280\end{array}$ & $\begin{array}{l}\text { C1: } 430 \\
\text { C2: } 336 \\
\text { C3: } 384\end{array}$ & $\begin{array}{c}\text { C1: SA (Street and Schenk, 1981) } \\
\text { C2: Phenolics (Mostofa et al., 2013; Parri et al., 2020) } \\
\text { C3: Aromatic amino acids and peptides (Yang et al., } \\
\text { 2015) }\end{array}$ \\
\hline 10 dap & $\begin{array}{l}\text { C1: } 240 / 310 \\
\text { C2: } 285 \\
\text { C3: } 230 / 275\end{array}$ & $\begin{array}{c}\text { C1: } 436 \\
\text { C2: } 364 \\
\text { C3: } 312 / 358\end{array}$ & $\begin{array}{c}\text { C1: SA (Street and Schenk, 1981) } \\
\text { C2: IAA (Li, 2009) } \\
\text { C3: Aromatic amino acids and peptides (Yang et al., } \\
\text { 2015), Phenolics (Mostofa et al., 2013; Parri et al., 2020) }\end{array}$ \\
\hline 20 dap & $\begin{array}{l}\text { C1: } 240 / 310 \\
\text { C2: } 285 \\
\text { C3: } 230 / 270\end{array}$ & $\begin{array}{l}\text { C1: } 438 \\
\text { C2: } 366 \\
\text { C3: } 308\end{array}$ & $\begin{array}{c}\text { C1: SA (Street and Schenk, 1981) } \\
\text { C2: IAA (Li, 2009) } \\
\text { C3: Phenolics (Mostofa et al., 2013; Parri et al., 2020) }\end{array}$ \\
\hline 30 dap & $\begin{array}{l}\text { C1: } 235 / 310 \\
\text { C2: } 230 / 280\end{array}$ & $\begin{array}{l}\text { C1: } 440 \\
\text { C2: } 332\end{array}$ & $\begin{array}{l}\text { C1: SA (Street and Schenk, 1981) } \\
\text { C2: Aromatic amino acids and peptides (Yang et al., } \\
\text { 2015), Phenolics (Mostofa et al., 2013; Parri et al., 2020) }\end{array}$ \\
\hline
\end{tabular}

515

516 
517 Table 2. Peak assignments for ${ }^{1} \mathrm{H}$ NMR spectra of tomato root exudates. This table includes

518 identified peaks only. Spectra part I, II and III are indicated in supplemental figure 3.

519 Abbreviations: dap $=$ days after planting, $\mathrm{H}$ mult. $=\mathrm{H}$ multiplicity, $\mathrm{d}=$ doublet, $\mathrm{s}=$ singlet, $\mathrm{t}=$

520 triplet, $\mathrm{dt}=$ double of triplets, $\mathrm{m}=$ multiplet. Treatment abbreviations: $0=$ Tomato Root

521 Exudates Control, $0.1=$ Tomato Root Exudates from plants irrigated with $0.1 \mathrm{mg} \cdot \mathrm{mL}^{-1}$ chitosan.

522 Numbers in treatments correspond to the mean of maximum intensity of the peaks (arbitrary

523 units). Bold numbers indicate significant differences (ANOVA, $p<0.05$ ).

20 dap [Chitosan] $\left(\mathrm{mg} \cdot \mathrm{mL}^{-1}\right)$

\begin{tabular}{|c|c|c|c|c|c|c|c|}
\hline & & & & & & & \\
\hline $\begin{array}{l}\text { Part of } \\
\text { the } \\
\text { spectra }\end{array}$ & dap & $\begin{array}{l}\text { Peak } \\
\text { number }\end{array}$ & Compound & Shift (ppm) & $H$ mult. & 0 & 0.1 \\
\hline 1 & 20 & 13 & Leucine/Isoleucine & 0.94 & & 0.25475 & 0.17575 \\
\hline I & $\begin{array}{l}10-20- \\
30\end{array}$ & 36 & Lactate & 1.33 & $d$ & 0.35685 & 0.18225 \\
\hline I & 20 & 53 & Acetate & 1.92 & s & 4.7895 & 3.4135 \\
\hline I & $\begin{array}{l}10-20- \\
30\end{array}$ & 62 & Malate & 2.3 & $\mathrm{t}$ & 0.6217 & 0.5769 \\
\hline I & $\begin{array}{l}10-20- \\
30\end{array}$ & 64 & Malate & 2.41 & & 1.725 & 1.26 \\
\hline II & $20-30$ & 80 & Methanol & 3.36 & $s$ & 0.34845 & 0.2379 \\
\hline II & 20 & 99 & Raffinose & 4.99 & $d$ & 0.027535 & 0.03025 \\
\hline II & 20 & 100 & Glucose & 5.237 & $d$ & 0.02523 & 0.035445 \\
\hline ॥ & 20 & 103 & Raffinose & 5.42 & $d$ & 0.02462 & 0.02018 \\
\hline II & 20 & 105 & Uracil & 5.79 & $d$ & 0.031275 & 0.02049 \\
\hline III & 20 & 109 & $\begin{array}{c}\text { Cinnamic Acid / Fumaric } \\
\text { Acid }\end{array}$ & $6.52 / 6.51$ & $d / s$ & 0.2005 & 0.15425 \\
\hline III & 20 & 112 & p-Aminobenzoic Acid & 6.82 & $d$ & 0.0033845 & 0.0050605 \\
\hline III & 20 & 119 & Cinnamic Acid & 7.43 & $\mathrm{~m}$ & 0.049535 & 0.04216 \\
\hline III & 20 & 120 & Uracil & 7.52 & $d$ & 0.00791 & 0.016235 \\
\hline III & 20 & 121 & Cinnamic Acid & 7.62 & $\mathrm{dt}$ & 0 & 0.002784 \\
\hline III & 20 & 122 & p-Aminobenzoic Acid & 7.73 & $d$ & 0.0056825 & 0.00603 \\
\hline III & 20 & 125 & Trigonelline & 8.07 & $\mathrm{~m}$ & 0.006835 & 0.01239 \\
\hline III & $20-30$ & 129 & Formic Acid & 8.44 & $\mathrm{~m}$ & 0.35505 & 0.1718 \\
\hline III & 20 & 130 & Trigonelline & 8.82 & $\mathrm{~m}$ & 0.028845 & 0.022265 \\
\hline III & 20 & 131 & Trigonelline & 9.13 & s & 0.03144 & 0.024555 \\
\hline
\end{tabular}




\section{Figure Legends}

528 Figure 1. Chitosan depolarizes plasma membrane and damages tomato root cells. A, Variation

529 in membrane potential of root cells with chitosan. High doses ( 1 and $2 \mathrm{mg} \cdot \mathrm{mL}^{-1}$ ) of chitosan

530 significantly reduce membrane potential. B, High doses of chitosan damage root cells after $24 \mathrm{~h}$.

531 Red staining labels damaged cells while green staining labels living ones. Multifactorial ANOVA

532 was used to compare treatments (p-values $0.05\left(^{*}\right), 0.01\left(^{* *}\right), 0.001\left(^{* * *}\right)$ and $0.0001\left(^{(* * *)}\right)$.

533

534 Figure 2. Chitosan increases EEM fluorescence of tomato root exudates. A, Component 1

535 (Salicylic Acid); B, Component 2 (Phenolics and Salicylic Acid derivatives); C, Component 3

536 (Aromatic aa and Peptides). For Ex/Em coordinates of Components see Table 1. Abbreviations:

537 UF = fluorescence units, EEM = Emission Excitation Matrix. Multifactorial ANOVA was used to

538 compare treatments (p-values $0.05\left(^{*}\right), 0.01\left(^{* \star}\right), 0.001\left(^{(* \star}\right)$ and $\left.0.0001{ }^{(* \star *}\right)$ ).

539

540 Figure 3. Chitosan induces plant hormones. A-D figures correspond to hormone quantitation of 541 accumulated tomato root exudates over 3 days. A, Indole Acetic Acid; B, Salicylic Acid; C, 542 Jasmonic Acid; D, Abscisic Acid; E, Phytomelatonin quantitation in tomato roots. There is a 543 maximum level of hormones present in exudates from plants treated with $1 \mathrm{mg} \cdot \mathrm{mL}^{-1}$ chitosan.

544 Multifactorial ANOVA was used to compare treatments (p-values $\left.0.05\left(^{*}\right), 0.01\left(^{\star *}\right), 0.001{ }^{\star * *}\right)$ 545 and $\left.0.0001\left(^{* * * *}\right)\right)$.

547 Figure 4. EEM fluorescence dynamics of tomato root exudates. For Ex/Em coordinates of

548 Components see Table 1. Abbreviations: EEM = Emission Excitation Matrix, dap = days after 549 planting, $\mathrm{C} 1=$ Component $1, \mathrm{C} 2=$ Component $2, \mathrm{C} 3=$ Component 3 , UF = Fluorescence Units.

550 Mann-Whitney test was used for not normal distribution treatments. Welch's parametric test was 551 used for the remaining treatments ( $p$-values $0.05\left(^{*}\right), 0.01\left(^{* *}\right), 0.001\left(^{* \star *}\right)$ and $0.0001\left(^{(* \star *}\right)$ ).

553 Figure 5. Tomato rhizodeposition varies with time. Venn-diagram of ${ }^{1} \mathrm{H}$ Nuclear Magnetic 554 Resonance analyses peaks detected in tomato root exudates at 10,20 and 30 days after 555 planting.

557 Figure 6. Chitosan induces lipid signalling and defence compounds in tomato root exudates.

558 Partial Least Squares Regression Discriminant Analysis (PLSLDA) of HPLC-ESI-MS analysis of 559 pools of 20 days after planting tomato root exudates in modes positive (A) and negative (B).

560 Blue bars indicate a particular mass that differs from the control treatment. The larger the bar 561 size, the more noticeable the difference in intensity of the mass compared to the control.

563 Figure 7. Root exudates from plants treated with chitosan inhibit soil-borne pathogens. A, Effect 564 on hatching of Meloidogyne javanica eggs in tomato root exudates. Egg hatching is reduced ca. 5651.5 -fold. Multifactorial analysis Kruskal-Walis was performed to compare treatments ( $p$-values 
$\left.\left.5660.05\left(^{*}\right), 0.01{ }^{* *}\right), 0.001^{(* *}\right)$ and $\left.\left.0.0001^{(* * *}\right)\right)$. B, Growth kinetics of FORL in root exudates,

567 chitosan inhibits ca. 2-fold growth. C, Growth kinetics of $P$. chlamydosporia strain 123 in tomato

568 root exudates. Smoother Models were adjusted with band 0.75 and degree 2. Shadow area

569 stablishes the prediction confidence intervals at $95 \%$.

570

571

572 REFERENCES

573

574 Acemi A (2020) Chitosan versus plant growth regulators: a comparative analysis of their effects

575 on in vitro development of Serapias vomeracea (Burm.f.) Briq. Plant Cell Tiss Organ Cult 141:

$576 \quad 327-338$

577 Ahmad Z, Shahzad A, Sharma S (2019) Chitosan versus yeast extract driven elicitation for

578 enhanced production of fragrant compound 2-hydroxy-4-methoxybenzaldehyde (2H4MB) in root

579 tuber derived callus of Decalepis salicifolia (Bedd. ex Hook.f.) Venter. Plant Cell Tiss Organ Cult

580 136: $29-40$

581 Alberts B, Johnson A, Lewis J, Raff M, Roberts K, Walter P (2002) lon Channels and the

582 Electrical Properties of Membranes. Mol Biol Cell. 4th edition

583 Al-Hetar MY, Zainal Abidin MA, Sariah M, Wong MY (2011) Antifungal activity of chitosan

584 against Fusarium oxysporum f. sp. cubense. J Appl Polym Sci 120: 2434-2439

585 Arnao MB, Hernández-Ruiz J (2007) Melatonin promotes adventitious- and lateral root

586 regeneration in etiolated hypocotyls of Lupinus albus L. J Pineal Res 42: 147-152

587 Arnao MB, Hernández-Ruiz J (2018) Melatonin and its relationship to plant hormones. Ann Bot

588 121: 195-207

589 Arnao MB, Hernández-Ruiz J (2019a) Melatonin as a Chemical Substance or as

590 Phytomelatonin Rich-Extracts for Use as Plant Protector and/or Biostimulant in Accordance with

591 EC Legislation. Agron 9: 570

592 Arnao MB, Hernández-Ruiz J (2019b) Melatonin and reactive oxygen and nitrogen species: a

593 model for the plant redox network. Melatonin Res 2: 152-168

594 Arnao MB, Hernández-Ruiz J (2019c) Melatonin: A New Plant Hormone and/or a Plant Master

595 Regulator? Trends Plant Sci 24: 38-48

596 Asami T, Nakagawa Y (2018) Preface to the Special Issue: Brief review of plant hormones and

597 their utilization in agriculture. Pestic Sci 43: 154-158

598 Asgari-Targhi G, Iranbakhsh A, Ardebili ZO (2018) Potential benefits and phytotoxicity of bulk

599 and nano-chitosan on the growth, morphogenesis, physiology, and micropropagation of

600 Capsicum annuum. Plant Physiol Biochem 127: 393-402

601 Bais HP, Weir TL, Perry LG, Gilroy S, Vivanco JM (2006) The role of root exudates in

602 rhizosphere interactions with plants and other organisms. Annu Rev Plant Biol 57: 233-266

603 Baldrian P (2019) The known and the unknown in soil microbial ecology. FEMS Microbiol Ecol.

604 doi: $10.1093 /$ femsec/fiz005

605 Benhamou N (1996) Elicitor-induced plant defence pathways. Trends Plant Sci 1: 233-240 
606 Benhamou N, Thériault G (1992) Treatment with chitosan enhances resistance of tomato

607 plants to the crown and root rot pathogen Fusarium oxysporum f. sp. radicis-lycopersici. Physiol

608 Mol Plant P 41: 33-52

609 Berridge MJ (1993) Inositol trisphosphate and calcium signalling. Nature 361: 315-325

610 Blée E (2002) Impact of phyto-oxylipins in plant defense. Trends Plant Sci 7: 315-322

611 Böttcher C, Chapman A, Fellermeier F, Choudhary M, Scheel D, Glawischnig E (2014) The

612 Biosynthetic Pathway of Indole-3-Carbaldehyde and Indole-3-Carboxylic Acid Derivatives in

613 Arabidopsis. Plant Physiol 165: 841-853

614 Cervilla LM, Rosales MA, Rubio-Wilhelmi MM, Sánchez-Rodríguez E, Blasco B, Ríos JJ,

615 Romero L, Ruiz JM (2009) Involvement of lignification and membrane permeability in the

616 tomato root response to boron toxicity. Plant Sci 176: 545-552

617 Chanda B, Xia Y, Mandal MK, Yu K, Sekine K, Gao Q, Selote D, Hu Y, Stromberg A,

618 Navarre D, et al (2011) Glycerol-3-phosphate is a critical mobile inducer of systemic immunity

619 in plants. Nat Genet 43: 421-427

620 Cleveland WS (1979) Robust Locally Weighted Regression and Smoothing Scatterplots. J Am

621 Stat Assoc 74: 829-836

622 Colman SL, Salcedo MF, Mansilla AY, Iglesias MJ, Fiol DF, Martín-Saldaña S, Alvarez VA,

623 Chevalier AA, Casalongué CA (2019) Chitosan microparticles improve tomato seedling

624 biomass and modulate hormonal, redox and defense pathways. Plant Physiol Biochem 143:

$625 \quad 203-211$

626 Conconi A, Miquel M, Browse JA, Ryan CA (1996) Intracellular Levels of Free Linolenic and

627 Linoleic Acids Increase in Tomato Leaves in Response to Wounding. Plant Physiol 111: 797-

$628 \quad 803$

629 Cui L, Wang Z-Y, Zhou X-H (2012) Optimization of elicitors and precursors to enhance valtrate

630 production in adventitious roots of Valeriana amurensis Smir. ex Kom. Plant Cell Tiss Organ

631 Cult 108: 411-420

632 Czékus Z, Poór P, Tari I, Ördög A (2020) Effects of Light and Daytime on the Regulation of

633 Chitosan-Induced Stomatal Responses and Defence in Tomato Plants. Plants-Basel 9: 59

634 van Dam NM, Bouwmeester HJ (2016) Metabolomics in the Rhizosphere: Tapping into

635 Belowground Chemical Communication. Trends Plant Sci 21: 256-265

636 Dar TA, Uddin M, Khan MMA, Hakeem KR, Jaleel H (2015) Jasmonates counter plant stress:

637 A Review. Environ Exp Bot 115: 49-57

638 Dave A, Graham IA (2012) Oxylipin Signaling: A Distinct Role for the Jasmonic Acid Precursor

639 cis-(+)-12-Oxo-Phytodienoic Acid (cis-OPDA). Front Plant Sci. doi: 10.3389/fpls.2012.00042

640 El-Tantawy EM (2009) Behavior of Tomato Plants as Affected by Spraying with Chitosan and

641 Aminofort as Natural Stimulator Substances under Application of Soil Organic Amendments.

642 Pak J Biol Sci 12: 1164-1173

643 Elieh-Ali-Komi D, Hamblin MR (2016) Chitin and Chitosan: Production and Application of

644 Versatile Biomedical Nanomaterials. Int J Adv Res (Indore) 4: 411-427 
645 Escudero N, Marhuenda-Egea FC, Ibanco-Cañete R, Zavala-Gonzalez EA, Lopez-Llorca

646 LV (2014) A metabolomic approach to study the rhizodeposition in the tritrophic interaction:

647 tomato, Pochonia chlamydosporia and Meloidogyne javanica. Metabolomics 10: 788-804

648 Fooladi-Vanda G, Shabani L, Razavizadeh R (2019) Chitosan enhances rosmarinic acid

649 production in shoot cultures of Melissa officinalis $\mathrm{L}$. through the induction of methyl jasmonate.

650 Bot Stud 60: 26

651 Freed C, Adepoju O, Gillaspy G (2020) Can Inositol Pyrophosphates Inform Strategies for

652 Developing Low Phytate Crops? Plants-Basel 9: 115

653 Fürstenberg-Hägg J, Zagrobelny M, Bak S (2013) Plant Defense against Insect Herbivores.

654 Int J Mol Sci 14: 10242-10297

655 Gamborg OL, Miller RA, Ojima K (1968) Nutrient requirements of suspension cultures of

656 soybean root cells. Exp Cell Res 50: 151-158

657 Gunsé B, Poschenrieder C, RankI S, Schröeder P, Rodrigo-Moreno A, Barceló J (2016) A

658 highly versatile and easily configurable system for plant electrophysiology. MethodsX 3: 436-

659451

660 He W, Guo X, Xiao L, Feng M (2009) Study on the mechanisms of chitosan and its derivatives

661 used as transdermal penetration enhancers. Int J Pharm 382: 234-243

662 Hernández-Ruiz J, Cano A, Arnao MB (2005) Melatonin acts as a growth-stimulating

663 compound in some monocot species: Melatonin as growth promoter in plants. J Pineal Res 39:

$664 \quad 137-142$

665 Hirsch AM, Bauer WD, Bird DM, Cullimore J, Tyler B, Yoder JI (2003) Molecular signals and

666 receptors: controlling rhizosphere interactions between plants and other organisms. Ecology 84:

$667 \quad 858-868$

668 Hupp S, Rosenkranz M, Bonfig K, Pandey C, Roitsch T (2019) Noninvasive Phenotyping of

669 Plant-Pathogen Interaction: Consecutive In Situ Imaging of Fluorescing Pseudomonas

670 syringae, Plant Phenolic Fluorescence, and Chlorophyll Fluorescence in Arabidopsis Leaves.

671 Front Plant Sci 10: 1239

672 Iglesias MJ, Colman SL, Terrile MC, París R, Martín-Saldaña S, Chevalier AA, Álvarez VA,

673 Casalongué CA (2019) Enhanced Properties of Chitosan Microparticles over Bulk Chitosan on

674 the Modulation of the Auxin Signaling Pathway with Beneficial Impacts on Root Architecture in

675 Plants. J Agric Food Chem 67: 6911-6920

676 Iriti M, Faoro F (2008) Abscisic acid is involved in chitosan-induced resistance to tobacco

677 necrosis virus (TNV). Plant Physiol Biochem 46: 1106-1111

678 Jaime MD, Lopez-Llorca L, Conesa A, Lee AY, Proctor M, Heisler LE, Gebbia M, Giaever

679 G, Westwood J, Nislow C (2012) Identification of yeast genes that confer resistance to

680 chitosan oligosaccharide (COS) using chemogenomics. BMC Genomics 13: 267

681 Jaisi A, Panichayupakaranant $\mathbf{P}$ (2020) Enhanced plumbagin production in Plumbago indica

682 root culture by simultaneous and sequential dual elicitations using chitosan with L-alanine and

683 methyl-ß-cyclodextrin. Bioresour Bioprocess 7: 10 
684 Jones KH, Senft JA (1985) An improved method to determine cell viability by simultaneous

685 staining with fluorescein diacetate-propidium iodide. J Histochem Cytochem 33: 77-79

686 Kaur S, Dhillon GS (2014) The versatile biopolymer chitosan: potential sources, evaluation of

687 extraction methods and applications. Crit Rev Microbiol 40: 155-175

688 Li Y-N, Wu H-L, Zhu S-H, Nie J-F, Yu Y-J, Wang X-M, Yu R-Q (2009) Determination of indole-

689 3-acetic acid in soil using excitation-emission matrix fluorescence with trilinear decomposition-

690 based calibration methods. Anal Sci 25: 83-88

691 Lopez-Moya F, Escudero N, Zavala-Gonzalez EA, Esteve-Bruna D, Blázquez MA, Alabadí

692 D, Lopez-Llorca LV (2017) Induction of auxin biosynthesis and WOX5 repression mediate

693 changes in root development in Arabidopsis exposed to chitosan. Sci Rep 7: 16813

694 Ma B, Wang J, Liu C, Hu J, Tan K, Zhao F, Yuan M, Zhang J, Gai Z (2019) Preventive

695 Effects of Fluoro-Substituted Benzothiadiazole Derivatives and Chitosan Oligosaccharide

696 against the Rice Seedling Blight Induced by Fusarium oxysporum. Plants 8: 538

697 Majerus PW (1992) Inositol Phosphate Biochemistry. Annu Rev Biochem 61: 225-250

698 Malerba M, Cerana R (2016) Chitosan Effects on Plant Systems. Int J Mol Sci 17: 996

699 Mandal SM, Chakraborty D, Dey S (2010) Phenolic acids act as signaling molecules in plant-

700 microbe symbioses. Plant Signal Behav 5: 359-368

701 Marhuenda-Egea FC, Gonsálvez-Álvarez RD, Lledó-Bosch B, Ten J, Bernabeu R (2013)

702 New Approach for Chemometric Analysis of Mass Spectrometry Data. Anal Chem 85: 3053-

$703 \quad 3058$

704 Matzke AJM, Matzke M (2013) Membrane "potential-omics": toward voltage imaging at the cell

705 population level in roots of living plants. Front Plant Sci. doi: 10.3389/fpls.2013.00311

706 McClure MA, Kruk TH, Misaghi I (1973) A Method for Obtaining Quantities of Clean

707 Meloidogyne Eggs. J Nematol 5: 230

708 Meisrimler C-N, Planchon S, Renaut J, Sergeant K, Lüthje S (2011) Alteration of plasma

709 membrane-bound redox systems of iron deficient pea roots by chitosan. J Proteomics 74:

710 1437-1449

711 Mika A, Boenisch MJ, Hopff D, Lüthje S (2010) Membrane-bound guaiacol peroxidases from

712 maize (Zea mays L.) roots are regulated by methyl jasmonate, salicylic acid, and pathogen

713 elicitors. J Exp 61: 831-841

714 Miles Cl, Schenk GH (1970) Fluorescence of acetylsalicylic acid in solution and its

715 measurement in presence of salicylic acid. Anal Chem 42: 656-659

716 Mobed JJ, Hemmingsen SL, Autry JL, McGown LB (1996) Fluorescence Characterization of

717 IHSS Humic Substances: Total Luminescence Spectra with Absorbance Correction. Environ Sci

718 30: 3061-3065

719 Moon TS, Yoon S-H, Lanza AM, Roy-Mayhew JD, Prather KLJ (2009) Production of Glucaric

720 Acid from a Synthetic Pathway in Recombinant Escherichia coli. Appl Environ Microbiol 75:

$721 \quad 589-595$ 
bioRxiv preprint doi: https://doi.org/10.1101/2020.06.09.142653; this version posted June 11, 2020. The copyright holder for this preprint (which was not certified by peer review) is the author/funder, who has granted bioRxiv a license to display the preprint in perpetuity. It is made available under aCC-BY-NC-ND 4.0 International license.

722 Mostofa KMG, Yoshioka T, Mottaleb A, Vione D, eds (2013) Photobiogeochemistry of

723 Organic Matter: Principles and Practices in Water Environments. doi: 10.1007/978-3-642-

$724 \quad \underline{32223-5}$

725 Moustafa-Farag M, Almoneafy A, Mahmoud A, Elkelish A, Arnao MB, Li L, Ai S (2019)

726 Melatonin and Its Protective Role against Biotic Stress Impacts on Plants. Biomolecules 10: 54

727 Narula K, Elagamey E, Abdellatef MAE, Sinha A, Ghosh S, Chakraborty N, Chakraborty S

728 (2020) Chitosan-triggered immunity to Fusarium in chickpea is associated with changes in the

729 plant extracellular matrix architecture, stomatal closure and remodeling of the plant metabolome

730 and proteome. Plant J tpj. 14750

731 Ohno T, Bro R (2006) Dissolved Organic Matter Characterization Using Multiway Spectral

732 Decomposition of Fluorescence Landscapes. Soil Sci Soc Am J 70: 2028

733 Olivares-Bernabeu CM, López-Llorca LV (2002) Fungal egg-parasites of plant-parasitic

734 nematodes from Spanish soils. Rev Iberoam Micol 19: 104-110

735 Palma-Guerrero J, Jansson H-B, Salinas J, Lopez-Llorca LV (2007) Effect of chitosan on

736 hyphal growth and spore germination of plant pathogenic and biocontrol fungi. J Appl Microbiol

737 0: 071010063119021-???

738 Palma-Guerrero J, Lopez-Jimenez JA, Pérez-Berná AJ, Huang I-C, Jansson H-B, Salinas

739 J, Villalaín J, Read ND, Lopez-Llorca LV (2010) Membrane fluidity determines sensitivity of

740 filamentous fungi to chitosan. Mol Microbiol 75: 1021-1032

741 Pandey GK (2017) Mechanism of Plant Hormone Signaling under Stress. John Wiley \& Sons

742 Park CH, Yeo HJ, Park YE, Chun SW, Chung YS, Lee SY, Park SU (2019) Influence of

743 Chitosan, Salicylic Acid and Jasmonic Acid on Phenylpropanoid Accumulation in Germinated

744 Buckwheat (Fagopyrum esculentum Moench). Foods 8: 153

745 Parri E, Santinami G, Domenici V (2020) Front-Face Fluorescence of Honey of Different

746 Botanic Origin: A Case Study from Tuscany (Italy). Appl Sci 10: 1776

747 Pastor-Fernández J, Pastor V, Mateu D, Gamir J, Sánchez-Bel P, Flors V (2019)

748 Accumulating evidences of callose priming by indole- 3- carboxylic acid in response to

749 Plectospharella cucumerina. Plant Signal Behav 14: 1608107

750 Pitta-Alvarez SI, Giulietti AM (1999) Influence of chitosan, acetic acid an citric acid on growth

751 and tropane alkaloid production in transformed roots of Brugmansia candida - Effect of medium

$752 \mathrm{pH}$ and growth phase. Plant Cell Tiss Org 59: 31-38

753 Ravi Kumar MNV (2000) A review of chitin and chitosan applications. React Funct Polym 46:

$754 \quad 1-27$

755 Rodrigo-Moreno A, Andrés-Colás N, Poschenrieder C, Gunsé B, Peñarrubia L, Shabala S

756 (2013) Calcium- and potassium-permeable plasma membrane transporters are activated by

757 copper in Arabidopsis root tips: linking copper transport with cytosolic hydroxyl radical

758 production: Copper transport and hydroxyl radical production. Plant Cell Environ 36: 844-855

759 Salachna P, Zawadzińska A (2014) Effect of chitosan on plant growth, flowering and corms

760 yield of potted. J Ecol Eng 15: 97-102 
bioRxiv preprint doi: https://doi.org/10.1101/2020.06.09.142653; this version posted June 11, 2020. The copyright holder for this preprint (which was not certified by peer review) is the author/funder, who has granted bioRxiv a license to display the preprint in perpetuity. It is made available under aCC-BY-NC-ND 4.0 International license.

761 Samari E, Sharifi M, Ghanati F, Fuss E, Ahmadian Chashmi N (2020) Chitosan-induced

762 phenolics production is mediated by nitrogenous regulatory molecules: NO and PAs in Linum

763 album hairy roots. Plant Cell Tiss Organ Cult 140: 563-576

764 Savchenko TV, Zastrijnaja OM, Klimov VV (2014) Oxylipins and plant abiotic stress

765 resistance. Biochemistry Moscow 79: 362-375

766 Seo M, Jikumaru Y, Kamiya Y (2011) Profiling of Hormones and Related Metabolites in Seed

767 Dormancy and Germination Studies. In AR Kermode, ed, Seed Dormancy. Humana Press,

768 Totowa, NJ, pp 99-111

769 Singh M, Poddar NK, Singh D, Agrawal S (2020) Foliar application of elicitors enhanced the

770 yield of withanolide contents in Withania somnifera (L.) Dunal (variety, Poshita). 3 Biotech 10:

$771 \quad 157$

772 Sivanandhan G, Arun M, Mayavan S, Rajesh M, Mariashibu TS, Manickavasagam M,

773 Selvaraj N, Ganapathi A (2012) Chitosan enhances withanolides production in adventitious

774 root cultures of Withania somnifera (L.) Dunal. Ind Crop Prod 37: 124-129

775 Street KW, Schenk GH (1981) Spectrofluorometric determination of acetylsalicylic acid,

776 salicylamide, and salicyclic acid as an impurity in pharmaceutical preparations. J Pharm Sci 70:

$777 \quad 641-646$

778 Syeda AM, Riazunnisa K (2020) Data on GC-MS analysis, in vitro anti-oxidant and anti-

779 microbial activity of the Catharanthus roseus and Moringa oleifera leaf extracts. Data Brief 29:

780105258

781 Valette M, Rey M, Gerin F, Comte G, Wisniewski-Dyé F (2020) A common metabolomic

782 signature is observed upon inoculation of rice roots with various rhizobacteria. $\mathrm{J}$ Integr Plant

783 Biol 62: 228-246

784 Vasyukova NI, Zinov'eva SV, Udalova ZhV, Panina YaS, Ozeretskovskaya OL, Sonin MD

785 (2003) The role of salicylic acid in systemic resistance of tomato to nematodes. Dokl Biol Sci

786 391: 343-345

787 Verboven S, Hubert M (2005) LIBRA: a MATLAB library for robust analysis. Chemom Intell Lab

788 Syst 75 : $127-136$

789 Vivanco JM, Guimarães RL, Flores HE, Guimarães RL, Flores HE (2002) Underground Plant

790 Metabolism: The Biosynthetic Potential of Roots. Plant Root. doi: 10.1201/9780203909423-66

791 Walker TS, Bais HP, Halligan KM, Stermitz FR, Vivanco JM (2009) Correction to Metabolic

792 Profiling of Root Exudates of Arabidopsis thaliana. J Agric Food Chem 57: 9346-9346

793 Wang C, Huang X, Li Q, Zhang Y, Li J-L, Mou Z (2019) Extracellular pyridine nucleotides

794 trigger plant systemic immunity through a lectin receptor kinase/BAK1 complex. Nat Commun

795 10: 4810

796 War AR, Paulraj MG, War MY, Ignacimuthu S (2011) Role of salicylic acid in induction of plant

797 defense system in chickpea (Cicer arietinum L.). Plant Signal Behav 6: 1787-1792

798 Williams SP, Gillaspy GE, Perera IY (2015) Biosynthesis and possible functions of inositol

799 pyrophosphates in plants. Front Plant Sci. doi: $\underline{10.3389 / f p l s .2015 .00067}$ 
bioRxiv preprint doi: https://doi org/10 1101/2020.06.09.142653. this version posted June 11,2020. The copyright holder for this preprint (which was not certified by peer review) is the author/funder, who has granted bioRxiv a license to display the preprint in perpetuity. It is made available under aCC-BY-NC-ND 4.0 International license.

800 Yang G, Zhou B, Zhang X, Zhang Z, Wu Y, Zhang Y, Lü S, Zou Q, Gao Y, Teng L (2016)

801 Effects of Tomato Root Exudates on Meloidogyne incognita. PLoS ONE 11: e0154675

802 Yang H, Xiao X, Zhao X, Wu Y (2015) Intrinsic Fluorescence Spectra of Tryptophan, Tyrosine

803 and Phenyloalanine. doi: $10.2991 /$ icadme-15.2015.46

804 Yin H, Du Y, Dong Z (2016) Chitin Oligosaccharide and Chitosan Oligosaccharide: Two Similar

805 but Different Plant Elicitors. Front Plant Sci. doi: 10.3389/fpls.2016.00522

806 Yuan J, Zhang N, Huang Q, Raza W, Li R, Vivanco JM, Shen Q (2015) Organic acids from

807 root exudates of banana help root colonization of PGPR strain Bacillus amyloliquefaciens NJN-

808 6. Sci Rep. doi: $10.1038 /$ srep 13438

809 Zhang B, Weston PA, Gu L, Zhang B, Li M, Wang F, Tu W, Wang J, Weston LA, Zhang Z

810 (2019) Identification of phytotoxic metabolites released from Rehmannia glutinosa suggest their

811 importance in the formation of its replant problem. Plant Soil 441: 439-454 

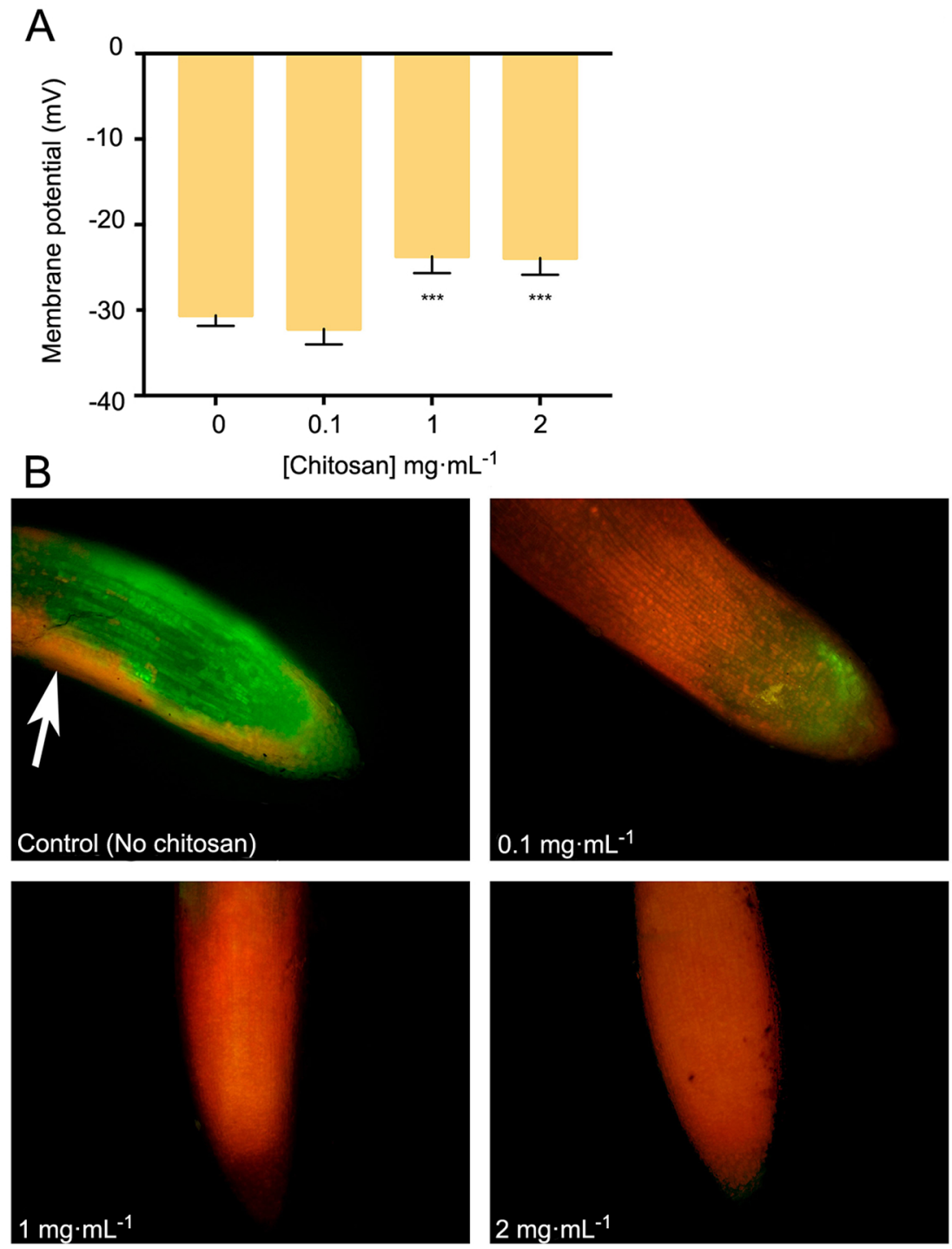

Figure 1. Chitosan depolarizes plasma membrane and damages tomato root cells. A, Variation in membrane potential of root cells with chitosan. High doses of chitosan (2 $\mathrm{mg} \cdot \mathrm{mL}^{-1}$ ) significantly reduce membrane potential. B, High doses of chitosan damage root cells after $24 \mathrm{~h}$. Red staining labels damaged cells while green staining labels living ones. Multifactorial ANOVA was used to compare treatments (p-values $0.05\left(^{*}\right)$, $\left.0.01{ }^{(* *}\right), 0.001\left(^{* \star *}\right)$ and $\left.\left.0.00011^{* \star * *}\right)\right)$. 


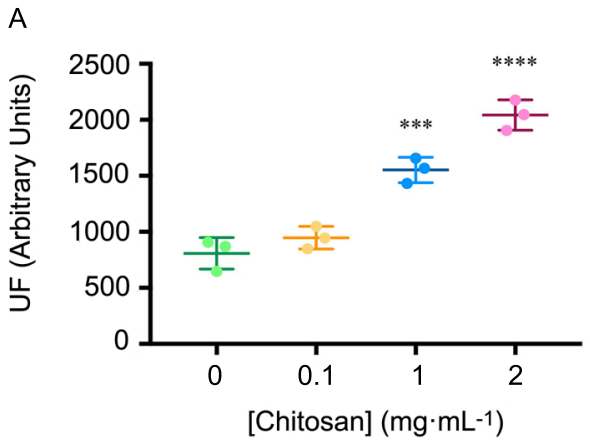

B

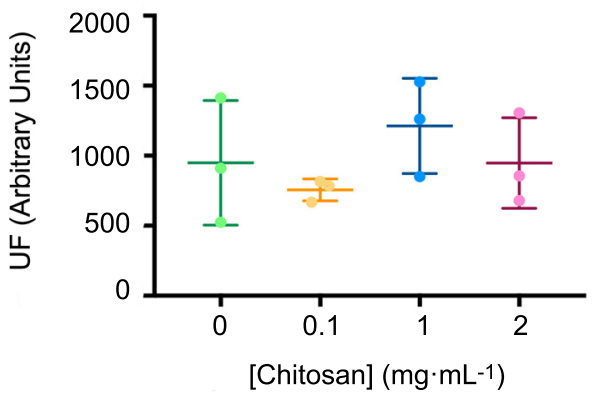

C

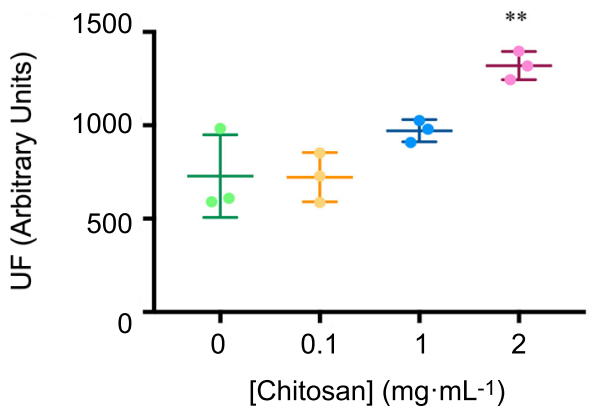

Figure 2. Chitosan increases EEM fluorescence of tomato root exudates. A, Component 1 (Salicylic Acid); B, Component 2 (Phenolics and Salicylic Acid derivatives); C, Component 3 (Aromatic aa and Peptides). For Ex/Em coordinates of Components see Table 1. Abbreviations: UF = fluorescence units, EEM = Emission Excitation Matrix. Multifactorial ANOVA was used to compare treatments (p-values $0.05\left(^{*}\right), 0.01\left(^{* *}\right)$, $0.001\left(^{* * *}\right)$ and $\left.0.00011^{* * *}\right)$ ). 

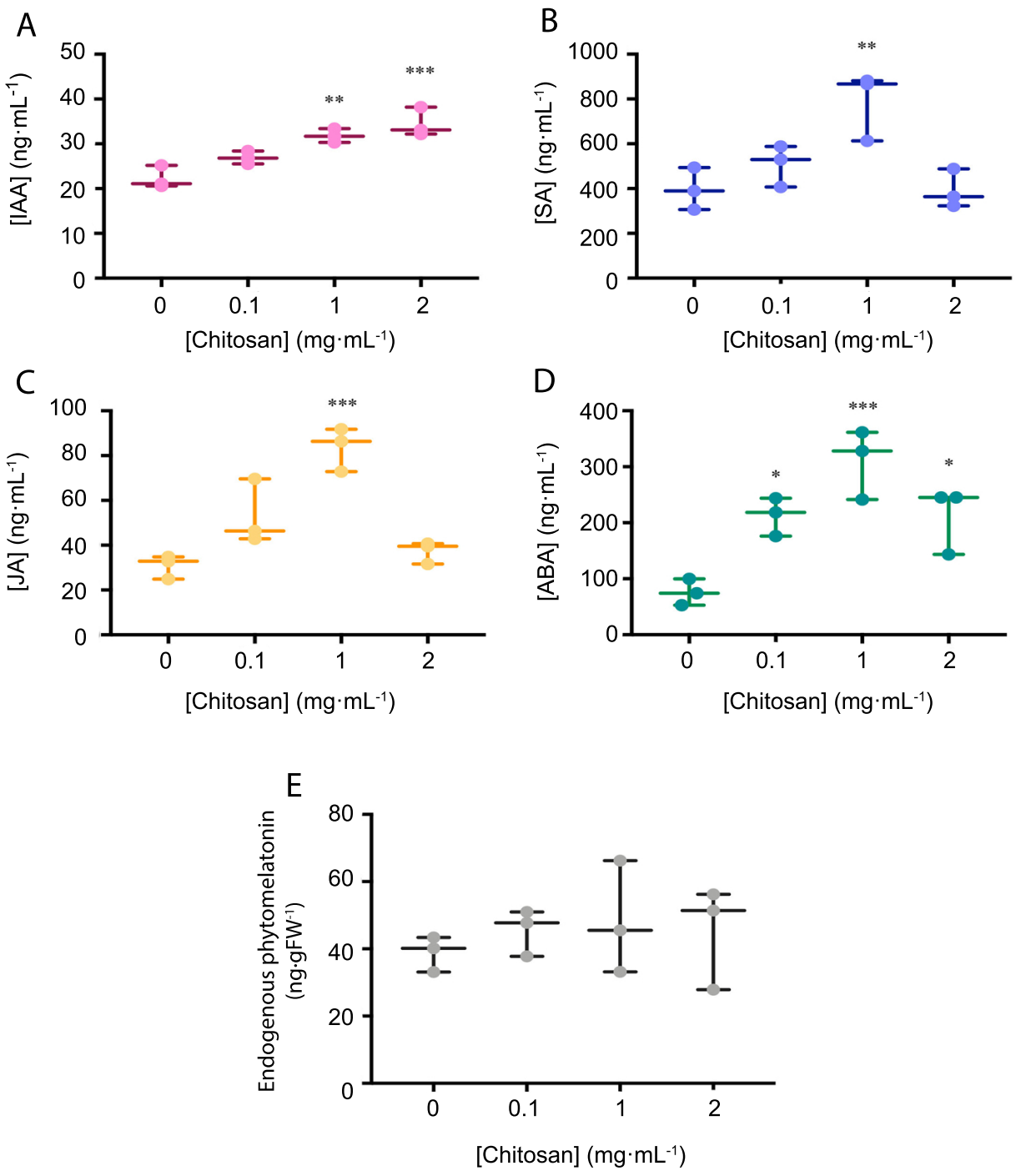

Figure 3. Chitosan increases EEM fluorescence of tomato root exudates. A, Component 1 (Salicylic Acid); B, Component 2 (Phenolics and Salicylic Acid derivatives); C, Component 3 (Aromatic aa and Peptides). For Ex/Em coordinates of Components see Table 1. Abbreviations: UF = fluorescence units, EEM = Emission Excitation Matrix.Multifactorial ANOVA was used to compare treatments (p-values $0.05\left(^{*}\right), 0.01\left(^{* *}\right), 0.001\left(^{* * *}\right)$ and $0.0001\left(^{* * * *}\right)$ ). 
10 dap

20 dap

30 dap

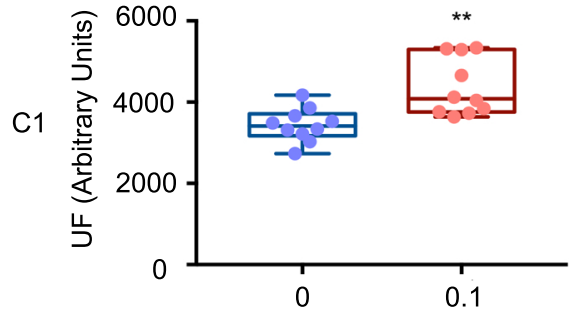

[Chitosan] (mg $\left.\cdot \mathrm{mL}^{-1}\right)$

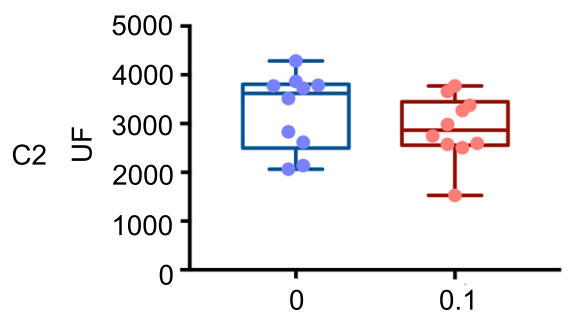

[Chitosan] $\left(\mathrm{mg} \cdot \mathrm{mL}^{-1}\right)$

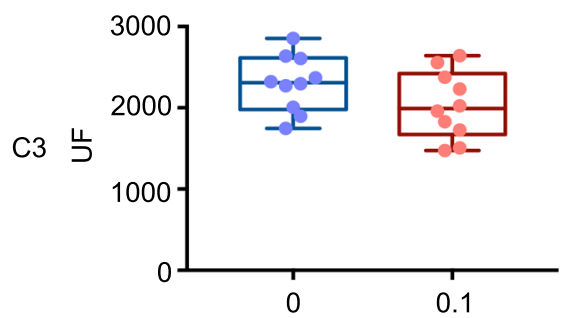

[Chitosan] (mg $\left.\mathrm{mL}^{-1}\right)$

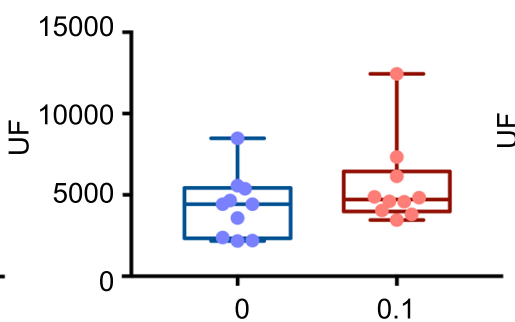

[Chitosan] $\left(\mathrm{mg} \cdot \mathrm{mL}^{-1}\right)$

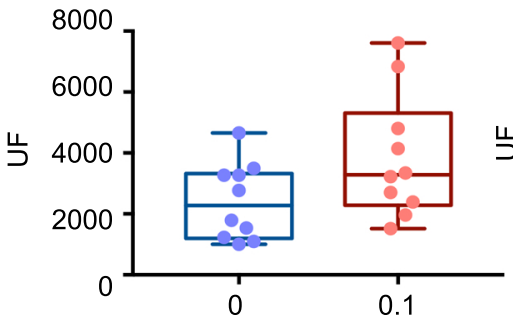

[Chitosan] $\left(\mathrm{mg} \cdot \mathrm{mL}^{-1}\right)$

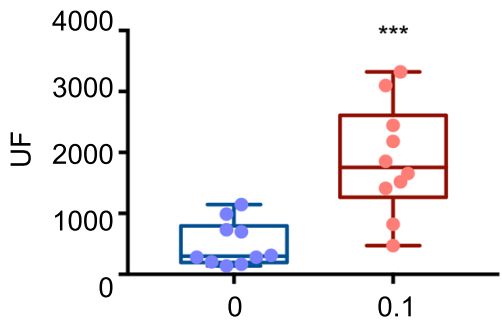

[Chitosan] $\left(\mathrm{mg} \cdot \mathrm{mL}^{-1}\right)$

Figure 4. EEM fluorescence dynamics of tomato root exudates. For Ex/Em coordinates of Components see Table 1. Abbreviations: $\mathrm{EEM}=$ Emission Excitation Matrix, dap $=$ days after planting, $\mathrm{C} 1=$ Component $1, \mathrm{C} 2=$ Component $2, \mathrm{C} 3=\mathrm{Component} 3$, UF $=$ Fluorescence Units. Mann-Whitney test was used for not normal distribution treatments. Welch's parametric test was used for the remaining treatments (p-values $0.05\left(^{*}\right), 0.01\left(^{* *}\right), 0.001\left(^{* * *}\right)$ and $\left.0.0001\left(^{* * *}\right)\right)$. 


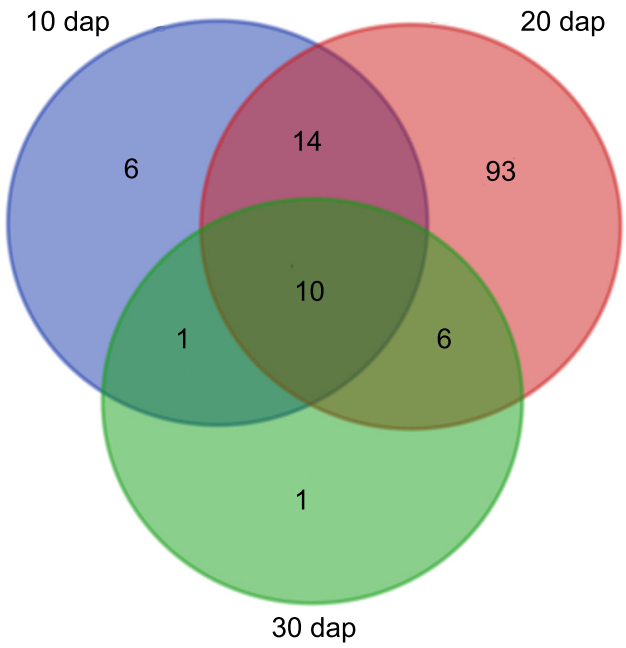

Figure 5. Tomato rhizodeposition varies with time. Venn-diagram of ${ }^{1} \mathrm{H}$ Nuclear Magnetic Resonance analyses peaks detected in tomato root exudates at 10,20 and 30 days after planting. 
A

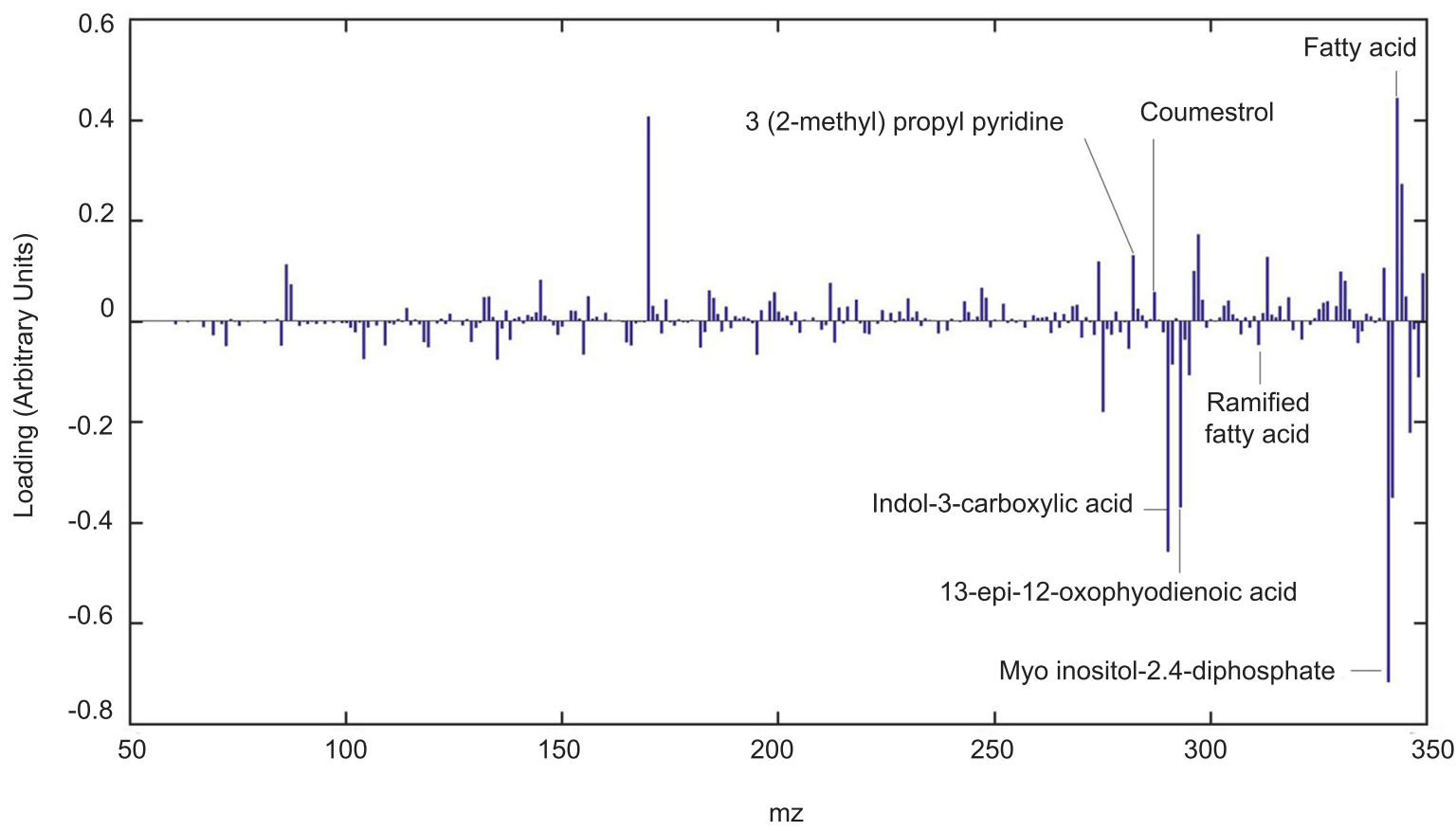

B

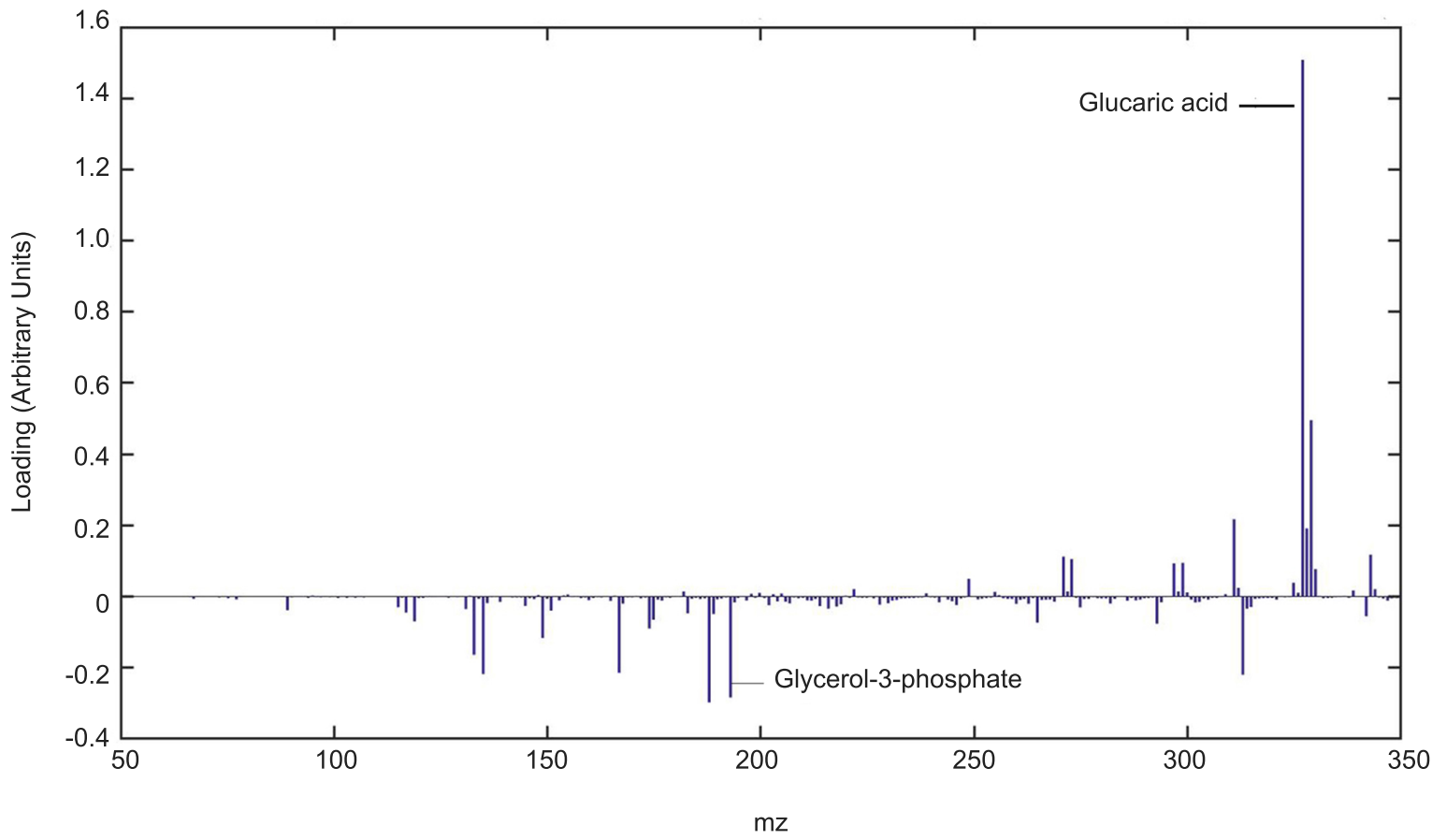

Figure 6. Chitosan induces lipid signalling and defence compounds in tomato root exudates. Partial Least Squares Regression Discriminant Analysis (PLSLDA) of HPLC-ESI-MS analysis of pools of 20 days after planting tomato root exudates in modes positive (A) and negative (B). Blue bars indicate a particular mass that differs from the control treatment. The larger the bar size, the more noticeable the difference in intensity of the mass compared to the control. 


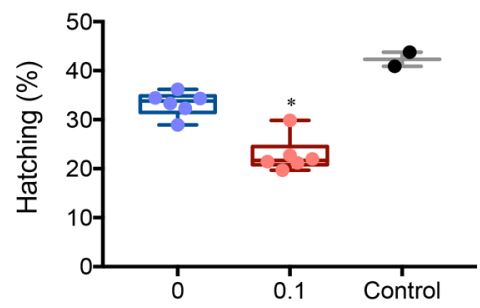

B [Chitosan] $\left(\mathrm{mg} \cdot \mathrm{mL}^{-1}\right)$ FORL

0.6

0.5

0.4

○

5.
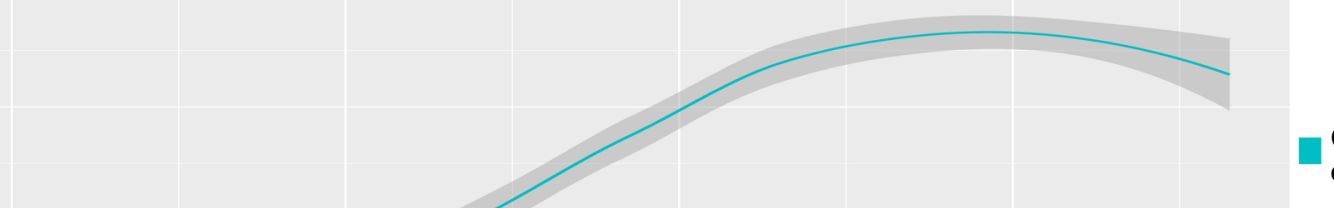

Control root exudates

$0.1 \mathrm{mg} \cdot \mathrm{mL}^{-1}$ chitosan root exudates

Control root exudates

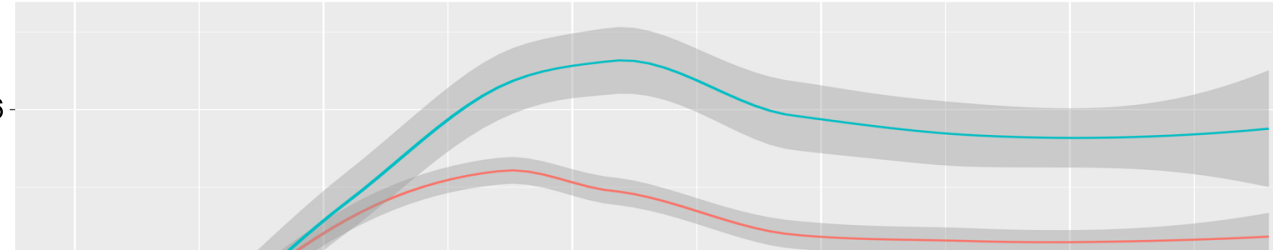

PC

$0.1 \mathrm{mg} \cdot \mathrm{mL}^{-1}$ chitosan root exudates

\section{2}

Figure 7. Root exudates from plants treated with chitosan inhibit soil-borne pathogens. A, Effect on hatching of Meloidogyne javanica eggs in tomato root exudates. Egg hatching is reduced ca. 1.5-fold. Multifactorial analysis Kruskal-Walis was performed to compare treatments (p-values $0.05\left(^{*}\right), 0.01\left(^{* \star}\right), 0.001\left(^{* \star \star}\right)$ and $\left.0.0001{ }^{(* \star \star}\right)$ ). B, Growth kinetics of FORL in root exudates, chitosan inhibits ca. 2-fold growth. C, Growth kinetics of P. chlamydosporia strain 123 in tomato root exudates. Smoother Models were adjusted with band 0.75 and degree 2 . Shadow area stablishes the prediction confidence intervals at $95 \%$. 


\section{Parsed Citations}

Acemi $A(2020)$ Chitosan versus plant growth regulators: a comparative analysis of their effects on in vitro development of

Serapias vomeracea (Burmf.) Briq. Plant Cell Tiss Organ Cult 141: 327-338

Pubmed: Author and Title

Google Scholar: Author Only Title Only Author and Title

Ahmad Z, Shahzad A, Sharma S (2019) Chitosan versus yeast extract driven elicitation for enhanced production of fragrant compound 2-hydroxy-4-methoxybenzaldehyde (2H4MB) in root tuber derived callus of Decalepis salicifolia (Bedd. ex Hook.f.) Venter. Plant Cell Tiss Organ Cult 136: 29-40

Pubmed: Author and Title

Google Scholar: Author Only Title Only Author and Title

Aberts B, Johnson A, Lewis J, Raff M, Roberts K, Walter P (2002) lon Channels and the Electrical Properties of Membranes. Mol Biol Cell. 4th edition

Pubmed: Author and Title

Google Scholar: Author Only Title Only Author and Title

A-Hetar MY, Zainal Abidin MA, Sariah M, Wong MY (2011) Antifungal activity of chitosan against Fusarium oxysporumf. sp. cubense. J Appl Polym Sci 120: 2434-2439

Pubmed: Author and Title

Google Scholar: Author Only Title Only Author and Title

Arnao MB, Hernández-Ruiz J (2007) Melatonin promotes adventitious- and lateral root regeneration in etiolated hypocotyls of Lupinus albus L. J Pineal Res 42: 147-152

Pubmed: Author and Title

Google Scholar: Author Only Title Only Author and Title

Arnao MB, Hernández-Ruiz J (2018) Melatonin and its relationship to plant hormones. Ann Bot 121: 195-207

Pubmed: Author and Title

Google Scholar: Author Only Title Only Author and Title

Arnao MB, Hernández-Ruiz J (2019a) Melatonin as a Chemical Substance or as Phytomelatonin Rich-Extracts for Use as Plant Protector and/or Biostimulant in Accordance with EC Legislation. Agron 9: 570

Pubmed: Author and Title

Google Scholar: Author Only Title Only Author and Title

Arnao MB, Hernández-Ruiz J (2019b) Melatonin and reactive oxygen and nitrogen species: a model for the plant redox network. Melatonin Res 2: 152-168

Pubmed: Author and Title

Google Scholar: Author Only Title Only Author and Title

Arnao MB, Hernández-Ruiz J (2019c) Melatonin: ANew Plant Hormone and/or a Plant Master Regulator? Trends Plant Sci 24: 3848

Asami T, Nakagawa Y (2018) Preface to the Special Issue: Brief review of plant hormones and their utilization in agriculture.

Pestic Sci 43: 154-158

Pubmed: Author and Title

Google Scholar: Author Only Title Only Author and Title

Asgari-Targhi G, Iranbakhsh A, Ardebili ZO (2018) Potential benefits and phytotoxicity of bulk and nano-chitosan on the growth, morphogenesis, physiology, and micropropagation of Capsicum annuum Plant Physiol Biochem 127: 393-402

Pubmed: Author and Title

Google Scholar: Author Only Title Only Author and Title

Bais HP, Weir TL, Perry LG, Gilroy S, Vivanco JM (2006) The role of root exudates in rhizosphere interactions with plants and other organisms. Annu Rev Plant Biol 57: 233-266

Pubmed: Author and Title

Google Scholar: Author Only Title Only Author and Title

Baldrian P (2019) The known and the unknown in soil microbial ecology. FEMS Microbiol Ecol. doi: 10.1093/femsec/fiz005

Pubmed: Author and Title

Google Scholar: Author Only Title Only Author and Title

Benhamou N (1996) Elicitor-induced plant defence pathways. Trends Plant Sci 1: 233-240

Pubmed: Author and Title

Google Scholar: Author Only Title Only Author and Title

Benhamou N, Thériault G (1992) Treatment with chitosan enhances resistance of tomato plants to the crown and root rot pathogen Fusarium oxysporumf. sp. radicis-lycopersici. Physiol Mol Plant P 41: 33-52

Pubmed: Author and Title 
Google Scholar: Author Only Title Only Author and Title

Berridge MJ (1993) Inositol trisphosphate and calcium signalling. Nature 361: 315-325

Pubmed: Author and Title

Google Scholar: Author Only Title Only Author and Title

Blée E (2002) Impact of phyto-oxylipins in plant defense. Trends Plant Sci 7: 315-322

Pubmed: Author and Title

Google Scholar: Author Only Title Only Author and Title

Böttcher C, Chapman A, Fellermeier F, Choudhary M, Scheel D, Glawischnig E (2014) The Biosynthetic Pathway of Indole-3-

Carbaldehyde and Indole-3-Carboxylic Acid Derivatives in Arabidopsis. Plant Physiol 165: 841-853

Pubmed: Author and Title

Google Scholar: Author Only Title Only Author and Title

Cervilla LM, Rosales MA, Rubio-Wilhelmi MM, Sánchez-Rodríguez E, Blasco B, Ríos JJ, Romero L, Ruiz JM (2009) Involvement of lignification and membrane permeability in the tomato root response to boron toxicity. Plant Sci 176: 545-552

Pubmed: Author and Title

Google Scholar: Author Only Title Only Author and Title

Chanda B, Xia Y, Mandal MK, Yu K, Sekine K, Gao Q, Selote D, Hu Y, Stromberg A, Navarre D, et al (2011) Glycerol-3-phosphate is a critical mobile inducer of systemic immunity in plants. Nat Genet 43: 421-427

Pubmed: Author and Title

Google Scholar: Author Only Title Only Author and Title

Cleveland WS (1979) Robust Locally Weighted Regression and Smoothing Scatterplots. J Am Stat Assoc 74: 829-836

Pubmed: Author and Title

Google Scholar: Author Only Title Only Author and Title

Colman SL, Salcedo MF, Mansilla AY, Iglesias MJ, Fiol DF, Martín-Saldaña S, Alvarez VA, Chevalier AA, Casalongué CA(2019)

Chitosan microparticles improve tomato seedling biomass and modulate hormonal, redox and defense pathways. Plant Physiol

Biochem 143: 203-211

Pubmed: Author and Title

Google Scholar: Author Only Title Only Author and Title

Conconi A, Miquel M, Browse JA, Ryan CA (1996) Intracellular Levels of Free Linolenic and Linoleic Acids Increase in Tomato

Leaves in Response to Wounding. Plant Physiol 111: 797-803

Pubmed: Author and Title

Google Scholar: Author Only Title Only Author and Title

Cui L, Wang Z-Y, Zhou X-H (2012) Optimization of elicitors and precursors to enhance valtrate production in adventitious roots of Valeriana amurensis Smir. ex Kom Plant Cell Tiss Organ Cult 108: 411-420

Pubmed: Author and Title

Google Scholar: Author Only Title Only Author and Title

Czékus Z, Poór P, Tari I, Ördög A(2020) Effects of Light and Daytime on the Regulation of Chitosan-Induced Stomatal Responses and Defence in Tomato Plants. Plants-Basel 9: 59

Pubmed: Author and Title

Google Scholar: Author Only Title Only Author and Title

van Dam NM, Bouwmeester HJ (2016) Metabolomics in the Rhizosphere: Tapping into Belowground Chemical Communication.

Trends Plant Sci 21: 256-265

Pubmed: Author and Title

Google Scholar: Author Only Title Only Author and Title

Dar TA, Uddin M, Khan MMA, Hakeem KR, Jaleel H (2015) Jasmonates counter plant stress: AReview. Environ Exp Bot 115: 49-57 Pubmed: Author and Title

Google Scholar: Author Only Title Only Author and Title

Dave A Graham IA (2012) Oxylipin Signaling: ADistinct Role for the Jasmonic Acid Precursor cis-(+)-12-Oxo-Phytodienoic Acid (cis-OPDA). Front Plant Sci. doi: 10.3389/fpls.2012.00042

Pubmed: Author and Title

Google Scholar: Author Only Title Only Author and Title

El-Tantawy EM (2009) Behavior of Tomato Plants as Affected by Spraying with Chitosan and Aminofort as Natural Stimulator

Substances under Application of Soil Organic Amendments. Pak J Biol Sci 12: 1164-1173

Pubmed: Author and Title

Google Scholar: Author Only Title Only Author and Title

Elieh-Ali-Komi D, Hamblin MR (2016) Chitin and Chitosan: Production and Application of Versatile Biomedical Nanomaterials. Int J Adv Res (Indore) 4: 411-427

Pubmed: Author and Title 
Google Scholar: Author Only Title Only Author and Title

Escudero N, Marhuenda-Egea FC, Ibanco-Cañete R, Zavala-Gonzalez EA, Lopez-Llorca LV (2014) Ametabolomic approach to study the rhizodeposition in the tritrophic interaction: tomato, Pochonia chlamydosporia and Meloidogyne javanica.

Metabolomics 10: 788-804

Pubmed: Author and Title

Google Scholar: Author Only Title Only Author and Title

Fooladi-Vanda G, Shabani L, Razavizadeh R (2019) Chitosan enhances rosmarinic acid production in shoot cultures of Melissa officinalis L. through the induction of methyl jasmonate. Bot Stud 60: 26

Pubmed: Author and Title

Google Scholar: Author Only Title Only Author and Title

Freed C, Adepoju O, Gillaspy G (2020) Can Inositol Pyrophosphates Inform Strategies for Developing Low Phytate Crops? PlantsBasel 9: 115

Fürstenberg-Hägg J, Zagrobelny M, Bak S (2013) Plant Defense against Insect Herbivores. Int J Mol Sci 14: 10242-10297

Pubmed: Author and Title

Google Scholar: Author Only Title Only Author and Title

Gamborg OL, Miller RA, Ojima K (1968) Nutrient requirements of suspension cultures of soybean root cells. Exp Cell Res 50: 151158

Pubmed: Author and Title

Google Scholar: Author Only Title Only Author and Title

Gunsé B, Poschenrieder C, Rankl S, Schröeder P, Rodrigo-Moreno A, Barceló J (2016) A highly versatile and easily configurable system for plant electrophysiology. MethodsX 3: 436-451

Pubmed: Author and Title

Google Scholar: Author Only Title Only Author and Title

He W, Guo X, Xiao L, Feng M (2009) Study on the mechanisms of chitosan and its derivatives used as transdermal penetration enhancers. Int J Pharm 382: 234-243

Pubmed: Author and Title

Google Scholar: Author Only Title Only Author and Title

Hernández-Ruiz J, Cano A, Arnao MB (2005) Melatonin acts as a growth-stimulating compound in some monocot species:

Melatonin as growth promoter in plants. J Pineal Res 39: 137-142

Pubmed: Author and Title

Google Scholar: Author Only Title Only Author and Title

Hirsch AM, Bauer WD, Bird DM, Cullimore J, Tyler B, Yoder Jl (2003) Molecular signals and receptors: controlling rhizosphere interactions between plants and other organisms. Ecology 84: 858-868

Pubmed: Author and Title

Google Scholar: Author Only Title Only Author and Title

Hupp S, Rosenkranz M, Bonfig K, Pandey C, Roitsch T (2019) Noninvasive Phenotyping of Plant-Pathogen Interaction: Consecutive In Situ Imaging of Fluorescing Pseudomonas syringae, Plant Phenolic Fluorescence, and Chlorophyll Fluorescence in Arabidopsis Leaves. Front Plant Sci 10: 1239

Pubmed: Author and Title

Google Scholar: Author Only Title Only Author and Title

Iglesias MJ, Colman SL, Terrile MC, París R, Martín-Saldaña S, Chevalier AA, Álvarez VA, Casalongué CA(2019) Enhanced Properties of Chitosan Microparticles over Bulk Chitosan on the Modulation of the Auxin Signaling Pathway with Beneficial Impacts on Root Architecture in Plants. J Agric Food Chem 67: 6911-6920

Pubmed: Author and Title

Google Scholar: Author Only Title Only Author and Title

Iriti M, Faoro F (2008) Abscisic acid is involved in chitosan-induced resistance to tobacco necrosis virus (TNV). Plant Physiol Biochem 46: 1106-1111

Pubmed: Author and Title

Google Scholar: Author Only Title Only Author and Title

Jaime MD, Lopez-Llorca L, Conesa A, Lee AY, Proctor M, Heisler LE, Gebbia M, Giaever G, Westwood J, Nislow C (2012)

Identification of yeast genes that confer resistance to chitosan oligosaccharide (COS) using chemogenomics. BMC Genomics 13:

267

Pubmed: Author and Title

Google Scholar: Author Only Title Only Author and Title

Jaisi A Panichayupakaranant P (2020) Enhanced plumbagin production in Plumbago indica root culture by simultaneous and sequential dual elicitations using chitosan with L-alanine and methyl- $\beta$-cyclodextrin. Bioresour Bioprocess 7: 10

Pubmed: Author and Title 
Google Scholar: Author Only Title Only Author and Title

Jones KH, Senft JA(1985) An improved method to determine cell viability by simultaneous staining with fluorescein diacetatepropidium iodide. J Histochem Cytochem 33: 77-79

Pubmed: Author and Title

Google Scholar: Author Only Title Only Author and Title

Kaur S, Dhillon GS (2014) The versatile biopolymer chitosan: potential sources, evaluation of extraction methods and applications. Crit Rev Microbiol 40: 155-175

Pubmed: Author and Title

Google Scholar: Author Only Title Only Author and Title

Li Y-N, Wu H-L, Zhu S-H, Nie J-F, Yu Y-J, Wang X-M, Yu R-Q (2009) Determination of indole-3-acetic acid in soil using excitationemission matrix fluorescence with trilinear decomposition-based calibration methods. Anal Sci 25: 83-88

Pubmed: Author and Title

Google Scholar: Author Only Title Only Author and Title

Lopez-Moya F, Escudero N, Zavala-Gonzalez EA, Esteve-Bruna D, Blázquez MA, Alabadí D, Lopez-Llorca LV (2017) Induction of auxin biosynthesis and WOX5 repression mediate changes in root development in Arabidopsis exposed to chitosan. Sci Rep 7: 16813

Pubmed: Author and Title

Google Scholar: Author Only Title Only Author and Title

Ma B, Wang J, Liu C, Hu J, Tan K, Zhao F, Yuan M, Zhang J, Gai Z(2019) Preventive Effects of Fluoro-Substituted

Benzothiadiazole Derivatives and Chitosan Oligosaccharide against the Rice Seedling Blight Induced by Fusarium oxysporum Plants 8: 538

Pubmed: Author and Title

Google Scholar: Author Only Title Only Author and Title

Majerus PW(1992) Inositol Phosphate Biochemistry. Annu Rev Biochem 61: 225-250

Pubmed: Author and Title

Google Scholar: Author Only Title Only Author and Title

Malerba M, Cerana R (2016) Chitosan Effects on Plant Systems. Int J Mol Sci 17: 996

Pubmed: Author and Title

Google Scholar: Author Only Title Only Author and Title

Mandal SM, Chakraborty D, Dey S (2010) Phenolic acids act as signaling molecules in plant-microbe symbioses. Plant Signal

Behav 5: 359-368

Pubmed: Author and Title

Google Scholar: Author Only Title Only Author and Title

Marhuenda-Egea FC, Gonsálvez-Álvarez RD, Lledó-Bosch B, Ten J, Bernabeu R (2013) New Approach for Chemometric Analysis of Mass Spectrometry Data. Anal Chem 85: 3053-3058

Pubmed: Author and Title

Google Scholar: Author Only Title Only Author and Title

Matzke AJM, Matzke M (2013) Membrane "potential-omics": toward voltage imaging at the cell population level in roots of living plants. Front Plant Sci. doi: 10.3389/fpls.2013.00311

Pubmed: Author and Title

Google Scholar: Author Only Title Only Author and Title

McClure MA, Kruk TH, Misaghi I (1973) A Method for Obtaining Quantities of Clean Meloidogyne Eggs. J Nematol 5: 230

Pubmed: Author and Title

Google Scholar: Author Only Title Only Author and Title

Meisrimler C-N, Planchon S, Renaut J, Sergeant K, Lüthje S (2011) Alteration of plasma membrane-bound redox systems of iron deficient pea roots by chitosan. J Proteomics 74: 1437-1449

Pubmed: Author and Title

Google Scholar: Author Only Title Only Author and Title

Mika A, Boenisch MJ, Hopff D, Lüthje S (2010) Membrane-bound guaiacol peroxidases from maize (Zea mays L.) roots are regulated by methyl jasmonate, salicylic acid, and pathogen elicitors. J Exp 61: 831-841

Pubmed: Author and Title

Google Scholar: Author Only Title Only Author and Title

Miles Cl, Schenk GH (1970) Fluorescence of acetylsalicylic acid in solution and its measurement in presence of salicylic acid. Anal Chem 42: 656-659

Pubmed: Author and Title

Google Scholar: Author Only Title Only Author and Title

Mobed JJ, Hemmingsen SL, Autry JL, McGown LB (1996) Fluorescence Characterization of IHSS Humic Substances: Total 
Luminescence Spectra with Absorbance Correction. Environ Sci 30: 3061-3065

Pubmed: Author and Title

Google Scholar: Author Only Title Only Author and Title

Moon TS, Yoon S-H, Lanza AM, Roy-Mayhew JD, Prather KLJ (2009) Production of Glucaric Acid from a Synthetic Pathway in

Recombinant Escherichia coli. Appl Environ Microbiol 75: 589-595

Pubmed: Author and Title

Google Scholar: Author Only Title Only Author and Title

Mostofa KMG, Yoshioka T, Mottaleb A Vione D, eds (2013) Photobiogeochemistry of Organic Matter: Principles and Practices in

Water Environments. doi: 10.1007/978-3-642-32223-5

Pubmed: Author and Title

Google Scholar: Author Only Title Only Author and Title

Moustafa-Farag M, Almoneafy A, Mahmoud A, Elkelish A, Arnao MB, Li L, Ai S (2019) Melatonin and Its Protective Role against

Biotic Stress Impacts on Plants. Biomolecules 10: 54

Pubmed: Author and Title

Google Scholar: Author Only Title Only Author and Title

Narula K, Elagamey E, Abdellatef MAE, Sinha A, Ghosh S, Chakraborty N, Chakraborty S (2020) Chitosan-triggered immunity to

Fusarium in chickpea is associated with changes in the plant extracellular matrix architecture, stomatal closure and remodeling of the plant metabolome and proteome. Plant J tpj.14750

Pubmed: Author and Title

Google Scholar: Author Only Title Only Author and Title

Ohno T, Bro R (2006) Dissolved Organic Matter Characterization Using Multiway Spectral Decomposition of Fluorescence

Landscapes. Soil Sci Soc Am J 70: 2028

Pubmed: Author and Title

Google Scholar: Author Only Title Only Author and Title

Olivares-Bernabeu CM, López-Llorca LV (2002) Fungal egg-parasites of plant-parasitic nematodes from Spanish soils. Rev Iberoam Micol 19: 104-110

Pubmed: Author and Title

Google Scholar: Author Only Title Only Author and Title

Palma-Guerrero J, Jansson H-B, Salinas J, Lopez-Llorca LV (2007) Effect of chitosan on hyphal growth and spore germination of plant pathogenic and biocontrol fungi. J Appl Microbiol 0: 071010063119021-???

Pubmed: Author and Title

Google Scholar: Author Only Title Only Author and Title

Palma-Guerrero J, Lopez-Jimenez JA, Pérez-Berná AJ, Huang I-C, Jansson H-B, Salinas J, Villalaín J, Read ND, Lopez-Llorca LV (2010) Membrane fluidity determines sensitivity of filamentous fungi to chitosan. Mol Microbiol 75: 1021-1032

Pubmed: Author and Title

Google Scholar: Author Only Title Only Author and Title

Pandey GK (2017) Mechanism of Plant Hormone Signaling under Stress. John Wiley \& Sons

Pubmed: Author and Title

Google Scholar: Author Only Title Only Author and Title

Park CH, Yeo HJ, Park YE, Chun SW, Chung YS, Lee SY, Park SU (2019) Influence of Chitosan, Salicylic Acid and Jasmonic Acid on Phenylpropanoid Accumulation in Germinated Buckwheat (Fagopyrum esculentum Moench). Foods 8: 153

Pubmed: Author and Title

Google Scholar: Author Only Title Only Author and Title

Parri E, Santinami G, Domenici V (2020) Front-Face Fluorescence of Honey of Different Botanic Origin: ACase Study from

Tuscany (Italy). Appl Sci 10: 1776

Pubmed: Author and Title

Google Scholar: Author Only Title Only Author and Title

Pastor-Fernández J, Pastor V, Mateu D, Gamir J, Sánchez-Bel P, Flors V (2019) Accumulating evidences of callose priming by indole- 3- carboxylic acid in response to Plectospharella cucumerina. Plant Signal Behav 14: 1608107

Pubmed: Author and Title

Google Scholar: Author Only Title Only Author and Title

Pitta-Alvarez SI, Giulietti AM (1999) Influence of chitosan, acetic acid an citric acid on growth and tropane alkaloid production in transformed roots of Brugmansia candida - Effect of medium pH and growth phase. Plant Cell Tiss Org 59: 31-38

Pubmed: Author and Title

Google Scholar: Author Only Title Only Author and Title

Ravi Kumar MNV (2000) A review of chitin and chitosan applications. React Funct Polym 46: 1-27

Pubmed: Author and Title

Google Scholar: Author Only Title Only Author and Title 
Rodrigo-Moreno A, Andrés-Colás N, Poschenrieder C, Gunsé B, Peñarrubia L, Shabala S (2013) Calcium- and potassiumpermeable plasma membrane transporters are activated by copper in Arabidopsis root tips: linking copper transport with cytosolic hydroxyl radical production: Copper transport and hydroxyl radical production. Plant Cell Environ 36: 844-855

Pubmed: Author and Title

Google Scholar: Author Only Title Only Author and Title

Salachna P, Zawadzińska A(2014) Effect of chitosan on plant growth, flowering and corms yield of potted. J Ecol Eng 15: 97-102 Pubmed: Author and Title

Google Scholar: Author Only Title Only Author and Title

Samari E, Sharifi M, Ghanati F, Fuss E, Ahmadian Chashmi N (2020) Chitosan-induced phenolics production is mediated by nitrogenous regulatory molecules: NO and PAs in Linum album hairy roots. Plant Cell Tiss Organ Cult 140: 563-576

Pubmed: Author and Title

Google Scholar: Author Only Title Only Author and Title

Savchenko TV, Zastrijnaja OM, Klimov W (2014) Oxylipins and plant abiotic stress resistance. Biochemistry Moscow 79: 362-375

Pubmed: Author and Title

Google Scholar: Author Only Title Only Author and Title

Seo M, Jikumaru Y, Kamiya Y (2011) Profiling of Hormones and Related Metabolites in Seed Dormancy and Germination Studies. In AR Kermode, ed, Seed Dormancy. Humana Press, Totowa, NJ, pp 99-111

Pubmed: Author and Title

Google Scholar: Author Only Title Only Author and Title

Singh M, Poddar NK, Singh D, Agrawal S (2020) Foliar application of elicitors enhanced the yield of withanolide contents in Withania somnifera (L.) Dunal (variety, Poshita). 3 Biotech 10: 157

Pubmed: Author and Title

Google Scholar: Author Only Title Only Author and Title

Sivanandhan G, Arun M, Mayavan S, Rajesh M, Mariashibu TS, Manickavasagam M, Selvaraj N, Ganapathi A(2012) Chitosan enhances withanolides production in adventitious root cultures of Withania somnifera (L.) Dunal. Ind Crop Prod 37: 124-129

Pubmed: Author and Title

Google Scholar: Author Only Title Only Author and Title

Street KW, Schenk GH (1981) Spectrofluorometric determination of acetylsalicylic acid, salicylamide, and salicyclic acid as an impurity in pharmaceutical preparations. J Pharm Sci 70: 641-646

Pubmed: Author and Title

Google Scholar: Author Only Title Only Author and Title

Syeda AM, Riazunnisa K (2020) Data on GC-MS analysis, in vitro anti-oxidant and anti-microbial activity of the Catharanthus roseus and Moringa oleifera leaf extracts. Data Brief 29: 105258

Pubmed: Author and Title

Google Scholar: Author Only Title Only Author and Title

Valette M, Rey M, Gerin F, Comte G, Wisniewski-Dyé F (2020) Acommon metabolomic signature is observed upon inoculation of rice roots with various rhizobacteria. J Integr Plant Biol 62: 228-246

Pubmed: Author and Title

Google Scholar: Author Only Title Only Author and Title

Vasyukova NI, Znov'eva SV, Udalova ZhV, Panina YaS, Ozeretskovskaya OL, Sonin MD (2003) The role of salicylic acid in systemic resistance of tomato to nematodes. Dokl Biol Sci 391: 343-345

Pubmed: Author and Title

Google Scholar: Author Only Title Only Author and Title

Verboven S, Hubert M (2005) LIBRA: a MATLAB library for robust analysis. Chemom Intell Lab Syst 75: 127-136

Pubmed: Author and Title

Google Scholar: Author Only Title Only Author and Title

Vivanco JM, Guimarães RL, Flores HE, Guimarães RL, Flores HE (2002) Underground Plant Metabolism: The Biosynthetic

Potential of Roots. Plant Root. doi: 10.1201/9780203909423-66

Pubmed: Author and Title

Google Scholar: Author Only Title Only Author and Title

Walker TS, Bais HP, Halligan KM, Stermitz FR, Vivanco JM (2009) Correction to Metabolic Profiling of Root Exudates of

Arabidopsis thaliana. J Agric Food Chem 57: 9346-9346

Pubmed: Author and Title

Google Scholar: Author Only Title Only Author and Title

Wang C, Huang X, Li Q, Zhang Y, Li J-L, Mou Z(2019) Extracellular pyridine nucleotides trigger plant systemic immunity through a lectin receptor kinase/BAK1 complex. Nat Commun 10: 4810

Pubmed: Author and Title

Google Scholar: Author Only Title Only Author and Title 
War AR, Paulraj MG, War MY, Ignacimuthu S (2011) Role of salicylic acid in induction of plant defense system in chickpea (Cicer arietinum L.). Plant Signal Behav 6: 1787-1792

Pubmed: Author and Title

Google Scholar: Author Only Title Only Author and Title

Williams SP, Gillaspy GE, Perera IY (2015) Biosynthesis and possible functions of inositol pyrophosphates in plants. Front Plant Sci. doi: 10.3389/fpls.2015.00067

Pubmed: Author and Title

Google Scholar: Author Only Title Only Author and Title

Yang G, Zhou B, Zhang X, Zhang Z, Wu Y, Zhang Y, Lü S, Zou Q, Gao Y, Teng L (2016) Effects of Tomato Root Exudates on Meloidogyne incognita. PLoS ONE 11: e0154675

Pubmed: Author and Title

Google Scholar: Author Only Title Only Author and Title

Yang H, Xiao X, Zhao X, Wu Y (2015) Intrinsic Fluorescence Spectra of Tryptophan, Tyrosine and Phenyloalanine. doi: 10.2991/icadme-15.2015.46

Pubmed: Author and Title

Google Scholar: Author Only Title Only Author and Title

Yin H, Du Y, Dong Z (2016) Chitin Oligosaccharide and Chitosan Oligosaccharide: Two Similar but Different Plant Elicitors. Front Plant Sci. doi: 10.3389/fpls.2016.00522

Pubmed: Author and Title

Google Scholar: Author Only Title Only Author and Title

Yuan J, Zhang N, Huang Q, Raza W, Li R, Vivanco JM, Shen Q (2015) Organic acids from root exudates of banana help root colonization of PGPR strain Bacillus amyloliquefaciens NJN-6. Sci Rep. doi: 10.1038/srep13438

Pubmed: Author and Title

Google Scholar: Author Only Title Only Author and Title

Zhang B, Weston PA, Gu L, Zhang B, Li M, Wang F, Tu W, Wang J, Weston LA, Zhang Z (2019) Identification of phytotoxic metabolites released from Rehmannia glutinosa suggest their importance in the formation of its replant problem. Plant Soil 441: 439-454

Pubmed: Author and Title

Google Scholar: Author Only Title Only Author and Title 